Research, part of a Special Feature on Resilience and Vulnerability of Arid and Semi-Arid Social Ecological Systems

\title{
Rebuilding Resilience in the Sahel: Regreening in the Maradi and Zinder Regions of Niger
}

\author{
$\underline{\text { Jan Sendzimir }}^{1}, \underline{\text { Chris P. Reij }}^{2}$, and $\underline{\text { Piotr Magnuszewski }}^{3}$
}

\begin{abstract}
The societies and ecosystems of the Nigerien Sahel appeared increasingly vulnerable to climatic and economic uncertainty in the late twentieth century. Severe episodes of drought and famine drove massive livestock losses and human migration and mortality. Soil erosion and tree loss reduced a woodland to a scrub steppe and fed a myth of the Sahara desert relentlessly advancing southward. Over the past two decades this myth has been shattered by the dramatic reforestation of more than 5 million hectares in the Maradi and Zinder Regions of Niger. No single actor, policy, or practice appears behind this successful regreening of the Sahel. Multiple actors, institutions and processes operated at different levels, times, and scales to initiate and sustain this reforestation trend. We used systems analysis to examine the patterns of interaction as biophysical, livelihood, and governance indicators changed relative to one another during forest decline and rebound. It appears that forest decline was reversed when critical interventions helped to shift the direction of reinforcing feedbacks, e.g., vicious cycles changed to virtuous ones. Reversals toward de-forestation or reforestation were preceded by institutional changes in governance, then livelihoods and eventually in the biophysical environment. Biophysical change sustained change in the other two domains until interventions introduced new ideas and institutions that slowed and then reversed the pattern of feedbacks. However, while society seems better at coping with economic or climatic shock or stress, the resilience of society and nature in the Maradi/Zinder region to global sources of uncertainty remains a pressing question in a society with one of the highest population growth rates on Earth.
\end{abstract}

Key Words: agro-forestry; farmer managed natural regeneration; Maradi Region; Niger; pastoralism; reforestation; regreening; resilience; vulnerability; West Africa; Zinder Region

\section{INTRODUCTION}

Since the late 1960 s, the persistent recurrence of drought and famine in the African Sahel cast the region as helpless before the inexorable advance of the Sahara desert (e.g., Lamprey 1975, but see Tucker et al. 1991, Nicholson et al. 1998, and Kerr 1998). Not only were national governments slow to recognize and respond to drought and famine (Mortimer and Adams 2001), but decades of foreign aid apparently failed to even mitigate deforestation, population growth, poverty, or periodic famine (Raynaut 1997, Wickens 1997). These factors marked the Sahel as an example of society's failure to cope with uncertainty from natural variability or socioeconomic change. However, a dramatic reversal of these trends over the past two decades in the Maradi and Zinder Regions (Maradi/Zinder hereafter) of Niger shows even resource-poor societies can climb out of crisis. Over an area of 5 million hectares of sparse scrubland, some 200 million trees have regreened the region and now secure the livelihoods of 4.5 million people (Reij 2006, WRI 2008). From the women whose daily foraging for firewood has declined from 3 hours to 30 minutes each day, to farmers who now export a surplus of vegetables to Nigeria, evidence suggests declining vulnerability and improved livelihoods for many in this social-ecological system (Larwanou et al. 2006, Tougiani et al. 2008, Reij et al. 2009). Perhaps success at this scale will encourage wider reporting of other "good news" stories of environmental rehabilitation and associated societal benefits from African farming systems (Tiffen et al. 1994, Wellard and Mortimore 2000, Scoones and Wolmer 2002, Reij 2006). 
The basis of this success has been ascribed to many factors ranging from increased rainfall, rural-urban migration (Olsson et al. 2005), bottom-up community development (Scherr and Sthapit 2009), changes in local management of resources (Reij 2006), and top-down policy reform (McGahuey and Winterbottom 2007). However, no study has systematically examined how all the potential factors interacted to promote this regreening. This paper addresses this gap with a systems analysis of interactions within and between the ecological, economic, and socio-political domains that might explain the changing dynamics of woodland cover over the past century. Specifically, we examine how shifts in causal relations account for the long woodland decline and then relatively rapid reversal since 1990. How such dynamics reflect changes in the vulnerability of Sahel social-ecological systems to stress and shock may provide indicators useful for managing the resilience of social-ecological system to uncertainty from climate change.

\section{Context: resilience of African farming systems}

The "regreening of the Sahel" (CILSS 2005) was a surprise bordering on revelation to those accustomed to the tree-sparse landscape in which most people tried to eke out a living in the 1980s. But the roots of this surprise run deeper to the basic paradigms with which experts frame the problems behind the region's declining resilience to change. This decline has been ascribed to a host of causes ranging from lack of technical capacity to remedy "dysfunctional" biophysical systems (a prejudice typical of "northern" societies; see Raynaut 1997), to dominance of international economic and political forces in forcing economic and social transformation. Policy failures are also blamed (WRI 2008) as is the loss of indigenous institutions such as property rights (Brough and Kimenyi 2004) that undermine the security of rangeland commons (Thébaud and Batterbury 2001). As Raynaut (1997) concludes: "There is always a deterministic streak running through these presentations ... through gross aggregation, the Sahel is reduced to a series of sweeping generalizations, a now-familiar lexicon of desertification, overpopulation, antiquated agriculture and irrational pastoralism." The sweep of these generalizations generated broad-ranging campaigns. Policies that applied these reforms to the exclusion of others never achieved sustainable growth let alone a halt of land degradation, a curb of population growth, a modernization of agriculture, or a reduction of pastoral-farmer conflict (CILSS 2005, CIRAD 2005) in Africa. Such failures were written off as mismanagement that was "technically inappropriate or poorly deployed" (Batterbury and Warren 2001). But the monodisciplinary conceptual foundations of such late twentieth century policy failures have driven the quest to build understanding on a broader, interdisciplinary base (Clark and Dickson 2003) and to integrate those threads in formulating and applying policy.

Parallel declines of both biophysical and socioeconomic domains in many semiarid socialecological systems in Africa suggest causal links that might involve interdisciplinary clusters of factors to bridge these domains. Several attempts to look across disciplines and scales and see how these clusters interact as a system in response to challenges like drought and famine have grouped them into three categories that roughly correspond to biophysical, economic, and socio-political domains. Krebs and Coe (1985) ascribed environmental degradation to agricultural practices, demographics, and culture. Von Braun et al. (1999) hold government responsible for famines, economic disaster, and political regime behavior. Anderson et al. (2002) contend that nature, wealth, and power must be jointly addressed in "revitalizing rural Africa." Investments in environmental, economic, and social capital are invoked to explain in part the regreening of the Sahel (WRI 2008).

For social-ecological systems in general, Fraser (2007) poses a three-space conceptual framework within which to examine how biophysical, economic, and socio-political factors vary as a system becomes more or less vulnerable to drought and famine. Very briefly, this framework suggests that comparatively small environmental problems will have commensurately large effects on food security, depending on the agro-ecological resilience, the diversity of livelihood options, and the capacity of formal and informal institutions to respond to crises within different food systems. The interplay between these three dimensions can potentially illuminate how vulnerability and adaptive capacity change along with resilience in influencing the long-term sustainability of socialecological systems.

We first give a more comprehensive background of the Sahel's historical trends over the past century and then use systems analysis within the Fraser 
conceptual framework to explore the question: What structure of causal relations between these three sets of factors explain the trajectory of Sahelian social-ecological systems as they lost and then regained resilience to change?

\section{The Nigerien Sahel: historical trends and the present context}

The Sahel (literally shore, littoral, or border in Arabic) is a semiarid interface running east-west from the Atlantic Ocean to the Red Sea, and between the arid Sahara desert in the north and the savannas and forests to the south. The nation of Niger (Fig. 1 ) is located west of the center of the Sahel corridor. Four vegetation zones (Sahara, Northern Sahel, Southern Sahel, and Northern Sudanian (Wezel et al. 2008)) correspond roughly to desert, semidesert, steppe, and brush-grass savanna. These zones reflect the banding of rainfall isohyets along a north-south gradient from less than $200 \mathrm{~mm} / \mathrm{y}$ up to $900 \mathrm{~mm} / \mathrm{y}$. Desert and semidesert dominate the northern two-thirds of Niger. The region over which regreening is estimated to have occurred is brushgrass savanna (mostly) and steppe.

Living in the Sahel requires constant learning and adaptation because it is a highly variable environment at all scales of space and time. Even in "normal" times without extreme events like drought or flooding, life's inherent uncertainty demands flexibility, imagination, and cooperation. As such, indigenous strategies do not shrink from adversity but reward diversity and experimentation such that " . . innovative farming practice confers social status and differentiates households in many dryland communities" (Mortimer and Adams 2001). At the spatial scale of fields, villages, and landscapes, Sahel farmers cope with high rainfall variability ("patchiness") every year (Swinton 1988) within very heterogeneous soils and bedrock (Raynaut 1997). The only common edaphic feature is that all soils, with the exception of some richer floodplain soils, have low fertility. This increases the importance of fertilizers and farming/fallow rotations (Raynaut 1997:20).

Over the past 10000 years, human communities over the entire Sahel have established, thrived, and moved to the rhythmic ebb and flow of the Saharan desert McIntosh 1993, (Furber 1997, Foley et al. 2003, Holmes 2008). The degree of aridity-e.g., arid, semiarid, subhumid-oscillates between decades and centuries, most recently shifting the $100-\mathrm{mm}$ and 500-mm rainfall contours southward by hundreds of kilometers between 1970 and 1985 (Fig. 1). However, this trend reversed around 1990 (Kerr 1998, Olsson et al. 2005) leading Hermann et al. (2005) to note that the nonuniform pattern of regreening suggests that other factors besides rainfall may have contributed to a differential greening response. The dramatic decline in on-farm tree density as soon as one crosses the border of Niger into Nigeria, where rainfall should be even higher, reveals that something happening in the society of Niger makes a difference. Furthermore, rainfall increased on average, but given the concentration of rainfall into fewer more extreme events (Lebel and Ali 2009) the Sahel would still have significant dry interludes between rain events, calling into question the degree to which rainfall really stimulated regreening. Any increase in extreme rainfall events could increase the frequency of floods and disturbances with far more local impacts than the regional droughts that this paper examines.

Extreme variability is also evident at the scale of nations. For example, in Niger, the past century was punctuated with outbreaks of conflicts, locusts, droughts, and famines (Fig. 2, see Appendix 3 for details). A series of decadal campaigns marked the rise and fall of French colonial influence as well as various phases of post-independence policy. Starting in the 1880 s, military campaigns to subjugate regional tribes gave way to political attempts to subordinate the national identity to France, remodel the economy for export, and secure reliable resource flows to France (Posthumus 2000). The 1920s campaign to "revitalize" the economy for export aimed to increase available resources by increasing the number of wells, and veterinary and medical services. However, failure by colonial authorities to clarify property rights (Brough and Kimenyi 2004) for the new wells led to overuse and the degradation of surrounding grazing areas when no recognized authority could clearly monitor and sanction well use. Traditionally, Tuareg clan chieftains negotiated use rights over networks of wells that allowed pastoral access across Niger and the surrounding region (Brough and Kimenyi 2004). The French campaign to reconfigure all infrastructure, management practices, and landscapes for export continued to erode local autonomy, culminating in the 1935 law that nationalized all natural resources in Niger. 
Fig. 1. Cities, regional boundaries, and vegetation zones of Niger, West Africa. The green outline shows an estimate of the area regreened in Maradi and Zinder regions of south-central Niger (source: USGS), and the hatched lines show the southward shift of the $100-\mathrm{mm}$ and $500-\mathrm{mm}$ rainfall isohyets during the drying trend from 1970 to the late 1980s (Koechlin 1997:17). The boundaries between vegetation zones are more gradual shifts in species distributions than sharp, distinct borders.

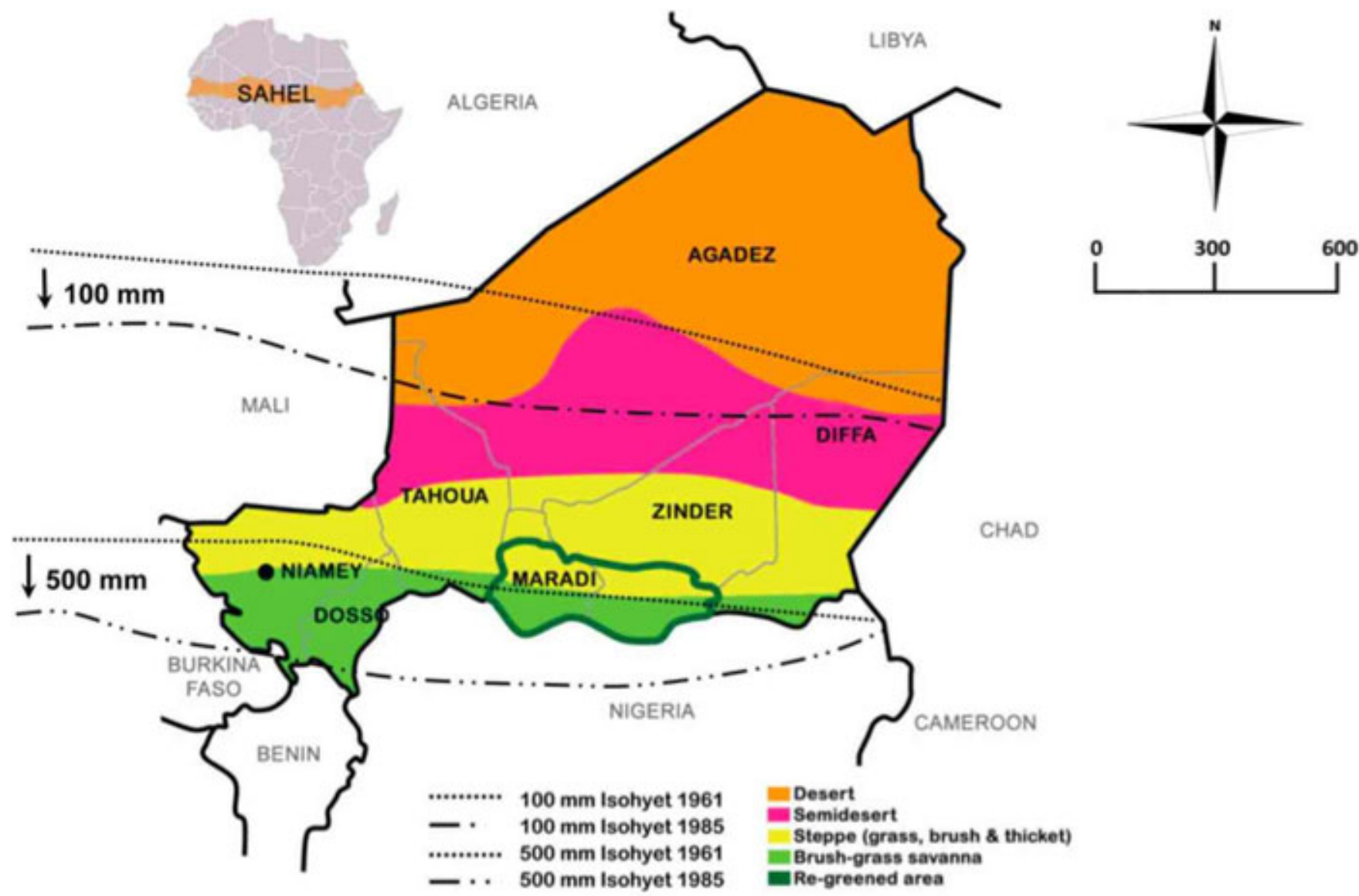

The political and economic landscapes of Niger changed dramatically after World War II. Against the background of rising resistance, especially in Algeria and Guinea, the French colonial regime disengaged, leading to full independence for Niger in 1960. At the same time, both the agro-export economy and the population began growing quickly, driven in part by a decade of high precipitation (Fig. 2) as well as by increasing integration with the French economy that was rebounding from World War II. Sharp increases in population growth rates may reflect the concurrent mortality declines and fertility increases of the classic Phase 1 of demographic transition (Raynaut 1997:37). An increasingly young population structure could delay the shift to Phase 2demographics stabilized when both mortality and fertility decrease. After 1950 the population doubled by 1970 and again by 1998 . The population growth rate in Niger of $3.7 \%$ in 2008 was one of the world's highest (Central Intelligence Agency 2008).

An intense drought in the early 1970s shook the nation's optimism that had been sustained by the French nuclear power industry which started exporting uranium from the region (Higgot 1980). However, the rural agricultural and pastoral base of Niger suffered severe famine. Livestock herds were also decimated; across the region herds declined by 
Fig. 2. Outbreaks of locusts, drought, and famine against the background of historical trends for population and rainfall in Niger in the twentieth century. Data sources for rainfall, from rain gauge stations across West Africa (L'Hôte et al. 200, Table 1). The "Sahelian annual rainfall index" reflects differences from the mean annual rainfall measured over the long term (1896 to 2000). Sources: Lahmeyer 2006 (population, Y-axis left side), Raynaut 1997 (drought and famine), and MacDonald 1986 (locust outbreaks data). Note: rainfall data aggregated to regional levels do not reflect more local and patchy patterns of rainfall, water scarcity, and famine.

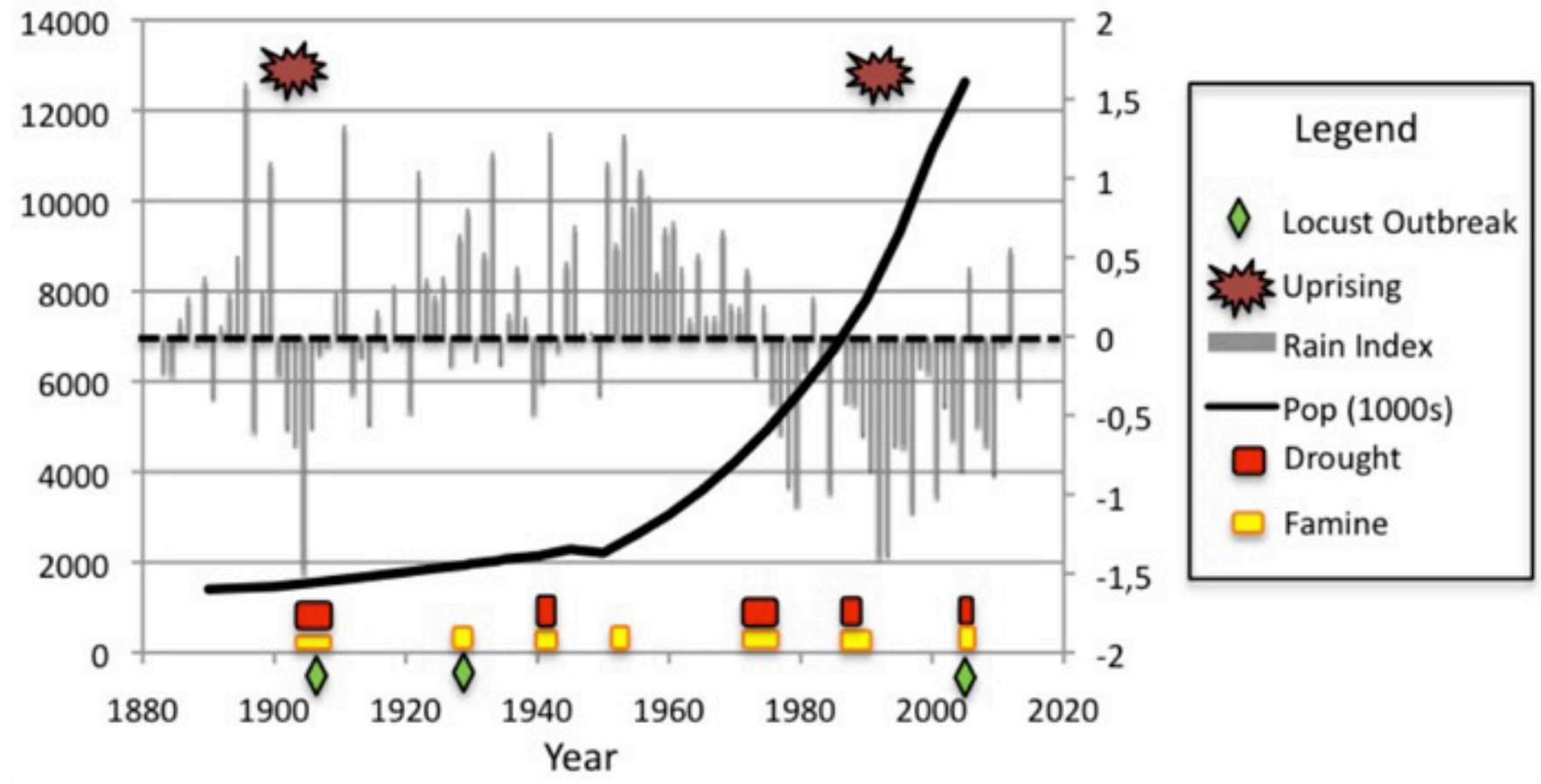

one-third while human mortality rate rose from 2.7 to $7 \%$ (USAID 1989, 2005a, 2005b). The famine provoked a decade of internationally funded projects applying technical solutions to improve food security and reforest the region. However, tree planting failed to reforest any area (20\% seedling survival rate), and enhanced intensive agriculture did not bolster food security or income (Tougiani et al. 2008). The reasons why such narrowly focused technical policies failed became clearer with the subsequent success of development policies and processes that tapped both nature and society.

The first successful experiments in reforestation were prompted in the early 1980s by the discovery of the "underground forest"- the deep root system that allowed "shrubs" to regrow into trees when pruned properly (Rinaudo 2001, Tougiani et al. 2008). The internationally based NGO, Serving in
Mission, identified, experimented with, and formalized these insights as a set of practices now known as farmer-managed natural regeneration (Cunningham and Abasse 2005). The principal tree species employed in farmer-managed natural regeneration include Bauhinia reticulata, Combretum spp., Ziziphus spina, and Z. mauritiaca; and, the most highly prized Faidherbia albida. Guiéra senegalensis, a drought-resistant shrub, also played an important role in providing animal fodder as well as firewood at the end of the dry season. Initially, only 12 farmers braved negative peer pressure to try farmer-managed natural regeneration (Tougiani et al. 2008) and turn cropped fields into open woodlands with row crops, e.g., millet, sorghum, cowpeas, peanuts, hibiscus, sesame, and cassava, planted in rotation between the trees to provide food and cash (Fig. 3). Such techniques challenged conventional wisdom that focused on export 
Fig. 3. Agro-forestry in the area in the Maradi/Zinder region of Niger which was regreened by farmermanaged natural regeneration methods.

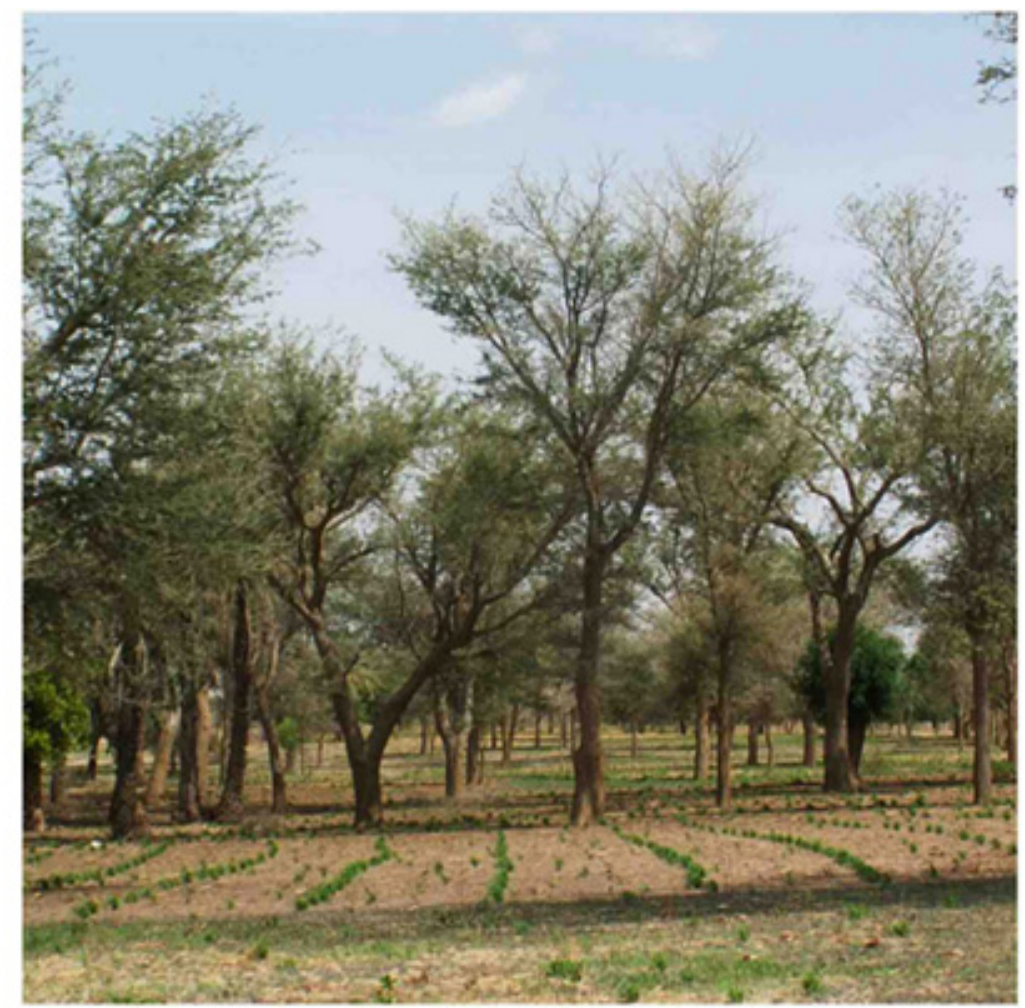

earnings (Tougiani et al. 2008). However, when another severe drought in 1985 devastated the livelihoods of hundreds of thousands of farmers, Serving in Mission offered a "food-for-work" program where the labor involved applying farmermanaged natural regeneration. When the rains returned, enough farmers continued to apply this approach that rumors of its success spread throughout the Maradi/Zinder region.

Establishing woodland agro-ecosystems required more than the better tree cultivation practices offered by farmer-managed natural regeneration. It also required changes in mentality and field practice, and in the institutions by which communities managed resources. Farmers and communities needed to become autonomous managers to experiment with farmer-managed natural regeneration. Without release from the often corrupt control of forestry officers, a quasi- paramilitary force that on occasion could perversely interpret the law so as to extract prohibitive fines, farmers saw trees more as sources of conflict than as resources. Feeling helpless to change the power structure, farmers often cut trees to avoid trouble (Tougiani et al. 2008).

Release from national authority began with a severe decline $(>120 \%$ drop in GDP) of the national economy in 1983 (Zanini 2009:2), but freedom from central control increased when President Kountché's death in 1987 opened a political vacuum that was not resolved until elections in 1999. This vacuum hobbled the national government and gave more autonomy to remote regions. Economically, the Maradi/Zinder region was constrained by dwindling economic reserves (uranium exports reduced by a moribund nuclear industry). And, without financial resources, forest agent interventions were confined to road checks for wood products; they no longer 
determined tree management in the field. In an atmosphere free of oversight by colonial or national authorities, farmers and communities took ownership of trees and the ways in which they farmed.

Freedom to experiment and improve farmermanaged natural regeneration was amplified by establishing the organizations to monitor, discuss, and enforce tree management in villages. Serving in Mission education programs linked fieldmanagement practices with the need to establish and apply social capital (sensu Pretty and Ward 2001). Specifically, the International Fund for Agricultural Development (IFAD) project supported the development of oversight committees in villages in the Aguié department, which empowered local people to decide how and when to apply farmermanaged natural regeneration. Farmers tested ideas in the fields as villagers "learned-by-doing" how to set up and run committees. As trees, and then economies, began to thrive, the image of local communities successfully managing themselves spread across the region, aided by NGO outreach campaigns. Within twenty years, an area larger than Cornwall or Rhode Island was covered with more than 200 million trees - an average expansion of $250000 \mathrm{ha} / \mathrm{y}$ if one assumes stocking at 20 to 150 trees/ha (Tougiani et al. 2008). Most regions of the Sahel have experienced increased rainfall since the late 1980s (Fig. 2), but few have witnessed the extent of regreening evident in the Maradi/Zinder region. The subsequent famine in 2005 was not as extreme as those of 1970 or 1985 , but a doubled human population demanded far more, and the national government and the international community were again tardy and inadequate in their responses. However, those in the regreened regions coped with the crisis far better because of the greater natural (wood biomass and fodder) and social (autonomous local governance) capital (WRI 2006, 2008; Reij et al. 2009).

\section{RESEARCH DESIGN AND METHODS}

The challenge of conducting an interdisciplinary synthesis is to avoid the bias of paradigmatic filters found at the extremes of the sciences. At one extreme, many social scientists view nature as " ... only an 'animate reflection of society' " (Descola 1986:10, Raynaut 1997:3). At the other extreme natural science assumes that biophysical factors wholly determine the range of society's options. The challenge of integrating natural and social factors increases when one assesses both at multiple levels. A diversity of factors working at field, village, regional, and national levels were important in regreening the Maradi/Zinder region, but were their parallel operations linked to contribute to this success? To answer this question we apply systems thinking and systems analysis (Senge 1990, Sterman 2000) to examine patterns of casual relations. Systems Dynamics is one of a variety of modeling languages that have been developed to integrate different perspectives while minimizing the biases inherent in various theoretical frameworks. The systems tools applied herecausal loop diagrams - are expandable as mathematical models but are used as concept maps to represent a range of hypotheses about the structure of relationships behind the degreening and regreening of the Sahel in Niger. Evidence for these causal loop diagrams was obtained from literature surveys and three decades of field experience in the Sahel (see Appendix for detailed explanations of system dynamics modeling protocols). Our central hypothesis is that resilience dynamics are reflected in a key trend in the twentieth century Nigerien Sahel: the loss and reemergence of woodland tree cover. Using anecdotal information garnered during 30 years of field work in the Sahel (C. Reij, personal communication) we inferred the prewar land-use pattern from literature (Leblanc et al. 2008) and the postwar pattern from aerial photographs and remote sensing imagery (Figure 4a, b, c) (Tappan and Cushing 2004, 2008). Together these data allowed us to sketch a stylized time series of deforestation and reforestation (Fig. 4d) that we refer to as the reference mode. The most dramatic losses of tree cover we attributed to prewar expansion of colonial agricultural exports. This occurred as institutional power over natural resources was centralized under colonial authorities in 1935. Following World War II, a rain-abetted export boom in the 1950s cleared even more trees from fields, and the drought-driven desperation for food and fuel drove further declines in tree density in the early 1970s (Fig. 4a, b).

We then used Vensim modeling software (Ventanna Systems, Inc.) to create causal loop diagrams to examine how ecological, economic, and sociopolitical factors might have interacted to generate these reference modes and influence the dynamics of resilience in the Maradi and Zinder Regions of Niger (referred to hereafter as the Maradi/Zinder region). The causal loop diagrams are supported by narratives in the Results section that clarify 
Fig. 4. Tree cover trends estimated as changes in tree density (unit = percent of precolonial tree cover): landscape dynamics in southwest Zinder. Remote sensing imagery courtesy of Dr. G. Tappan (Tappan and Cushing 2004, 2008). Scale is 1:5000. The 1975 aerial photos (1:50 000) were zoomed in to the specific terroir shown. Note: the emergence of a large village and severe shrinking of a wet area east of it may suggest that the 2005 image is of a different area, but all three images cover the identical geographical location.
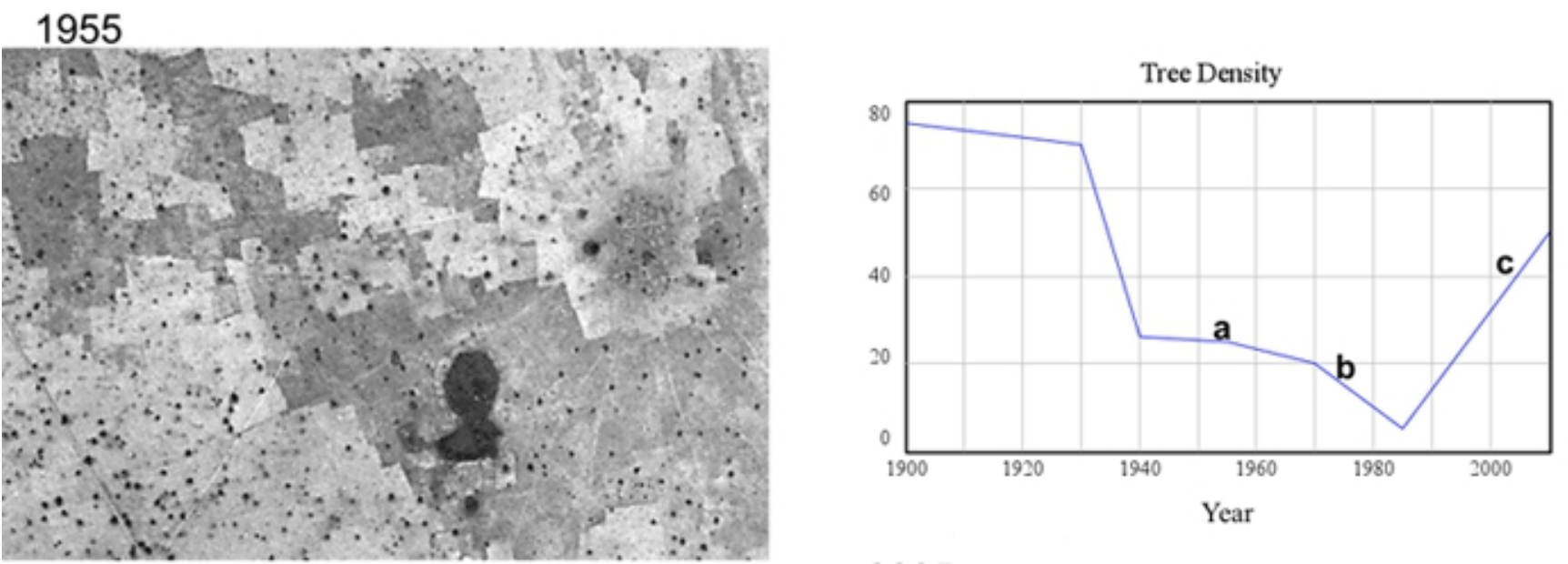

1975
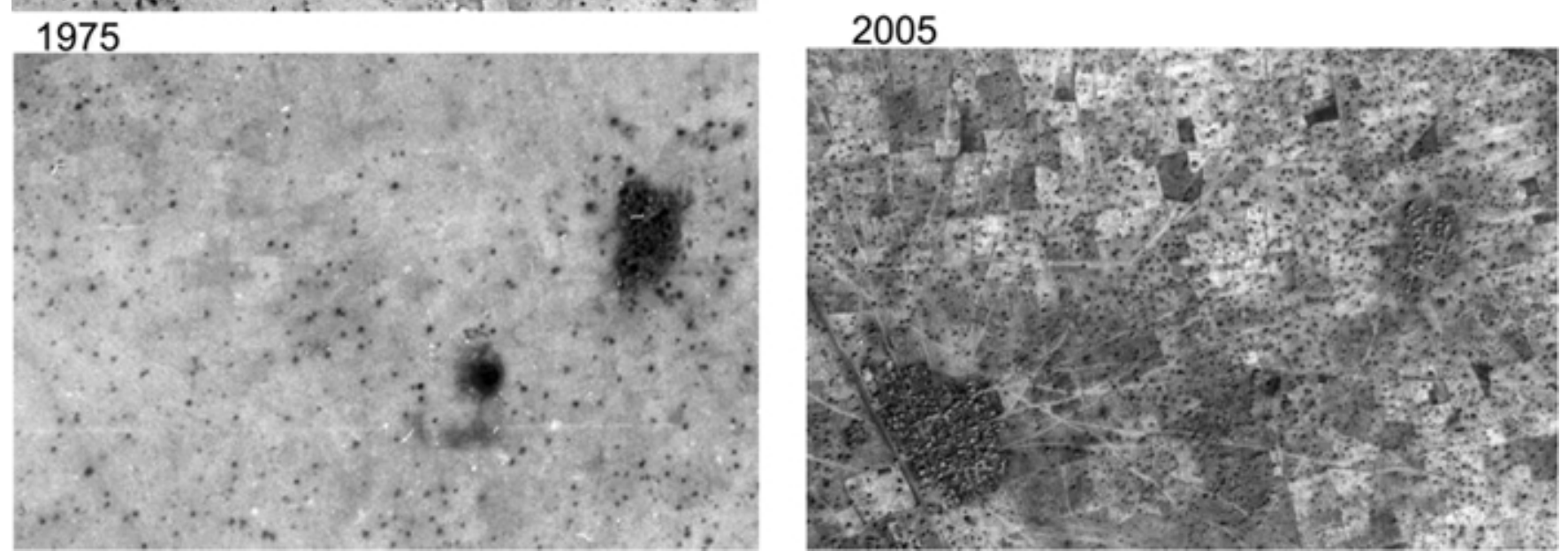

hypothetical interactions within and between the ecological, social, and economic domains that may have influenced the reference mode. Finally, we applied the Fraser conceptual framework (see Dougill et al. 2010 for a more detailed description) to examine how resilience dynamics are reflected in the trajectory of the Maradi/Zinder region in the three-dimensional space bounded by the ecological, economic, and socio-political domains. This was used as a weak test that hypothetical relations between these domains (graphically depicted in the causal loop diagrams) offer some insight into how and when the Sahel's resilience changed over the past century.

\section{RESULTS}

\section{Dynamic systems modeling to identify causal patterns}

Regreening after the 1985 drought began with NGO-mediated farming programs. The interplay between agro-ecological, economic, and sociopolitical factors is analyzed in the causal loop diagrams. These diagrams depict hypotheses about what factors or variables are involved in what structural patterns (circular chains or feedback loops of causality and webs of interactions) that helped drive the reference mode. Along a feedback loop a 
variable may change in value due to an impact from outside the loop or to a change of another variable's value within the loop. If the loop sustains the direction of change (ever higher or ever lower) then it is labeled $\mathrm{R}$ (reinforcing). If it reverses the direction of change then it is labeled $\mathrm{B}$ (balancing). In the text, variable names are italicized, and feedback loop names are enclosed in parentheses. See Appendix 1 for more details about systems dynamics logic used in causal loop diagrams and for tables that list which variables are linked in each feedback loop.

In the regreened area of the Maradi/Zinder region, tree density (Fig. 5) increased in the late 1980s when farmers became free to experiment with techniques rediscovered with NGO help. As the influence of national forestry officers diminished, the capacity of farmers and their communities to decide on a course of action, and to monitor and sanction use (e.g., local learning, and decision and enforcement capacity) increased. This discouraged tree theft and led to such novel silvicultural practices as carefully pruning "shrubs" in a way that released them to grow to full-sized trees. The resulting tree growth increased tree density and further reinforced the sense of ownership and other variables in the chain of feedbacks (Ra1). Increase in tree cover has been correlated with rainfall increases (Sheil and Murdiyarso 2008) that can be up to $30 \%$ (Gonzalez et al. 2007), which in turn encourages higher tree densities (Ra4) and suppresses drought impacts, thus encouraging tree growth ( $\mathrm{Ra} 3)$. Increasing tree density provided more seed pods and leaves (i.e., fodder) as well as shade, thereby attracting livestock. The combined inputs of fallen tree biomass and dung from birds (Soumare 1995) and livestock (Buerkert and Hiernaux 1998) increased soil fertility (Ra2) (Tougiani et al. 2008). Fertility also increased when increasing tree root mass fixed more nitrogen and pulled nutrients to the surface from deeper soil layers (Ra5). Increasing tree shelter attracted birds, thus enhancing seed dispersal, and it ameliorated field microclimates by lowering air temperature and wind speed, which in turn diminished evapotranspiration and sandblasting and abetted soil moisture and tree growth.

Farmers were further motivated to cultivate trees because trees provided the only avenue to intensify production. Their low income denied them access to synthetic fertilizers, and they had already exhausted other traditional means such as using fallow periods and cultivating marginal lands. Furthermore, population growth (Fig. 6) has driven demand for food and, hence, land clearance to the point where no fallow or marginal lands remain in the Maradi/Zinder region $(\mathrm{Bc} 3)$. However, tree cultivation improved field conditions (Leenders 2006) so quickly that farmers noted short-term signs of success in addition to better crop yields (Rc1): they no longer had to replant seeds that had been blown away (Larwanou et al. 2006) or covered by wind-blown sand (Rc2). Production was also enhanced by the dung from livestock which were attracted to the fodder and shelter. Field surveys of 400 farmers (Larwanou et al. 2006) in the Maradi/ Zinder region documented the farmers' perception that higher tree density correlates with lower planting frequency in order to successfully establish a crop. With a lag time of about 5 years from inception, tree density was also associated with higher soil fertility. This quantity is sufficient to feed 2.5 million people at an annual per capita cereal consumption of $200 \mathrm{~kg}$.

Increased tree density also provided a range of products (e.g., firewood and timber) that lowered the need to spend time or money on such items, thereby increasing household income beyond gains from increased crop production and export of vegetables to Nigeria. Increased yields from trees and crops provided the resources to employ more people to sustain yields with farmer-managed natural regeneration practices, thus reducing migration for work (to other towns, regions, or nations) and providing sufficient manpower to fully utilize dung and increase production (Mortimer and Adams 2001). However, population growth continues to drive demand for resources. Regreening based on farmer-managed natural regeneration has given rural communities respite, but for how long, given it has one of the highest birth rates in the world? This question is more complex than it first appears because environmental conditions (soil erosion and water quality) can sometimes improve as population density and agricultural intensity increase (Tiffen et al. 1994). While some (Boyd and Slaymaker 2000) find such cases to be the exception, the regreened areas of the Maradi/Zinder region have higher densities of trees and people than the regions west of them in Niger. Some regions in the West African Sahel, such as the Old Peanut Basin in Senegal, have higher densities of Faidherbia albida, but these are older artifacts, and are not so much the result of processes occurring over the last three decades (Gray Tappan, personal communication). 
Fig. 5. Trees and environment: relations between biophysical (trees, soil, water, and atmosphere) and socio-political (institutions, social capital), modeled at the field-to-village level.

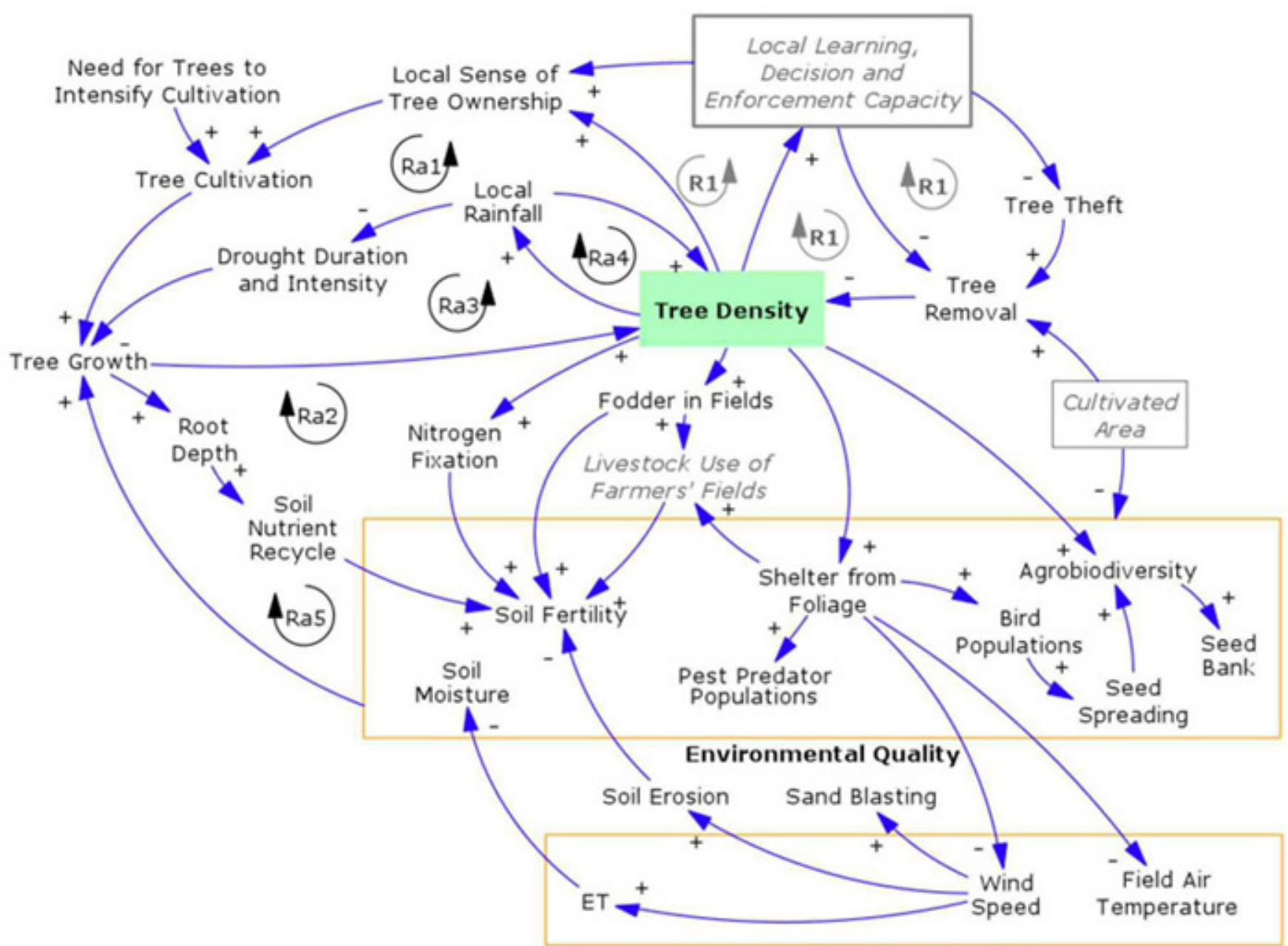

Field Microclimate

In traditional agricultural systems lacking the energy or technical resources to sufficiently boost production on individual farms, one tactic to address the high variability of resources (e.g., rainfall, grazing areas, field production) is to move cattle over wide regions to integrate that variability within the biophysical bounds of their fluctuating biomass (Fig. 7). Regreening increased fodder availability locally, thereby decreasing the need to move cattle over larger areas. However, that need always exists in the dynamic heterogeneity of the Sahel, and, combined with competition for fodder motivates farmers and herders to cooperate to avoid conflict. To minimize conflict created by inadvertent trespass onto their fields, farmers enhanced cooperation by clearly marking migration corridors for herders' livestock (Bd2). Relations improved further with inclusion, for the first time, of herders in the decision-making committees (monitoring and sanctioning use of fields) set up under NGO mediation (Bd1). Both increase local and regional capacity to "manage the "dynamism of common property' in shifting, heterogeneous landscapes" (Thébaud and Batterbury 2001). This is welcome but may prove temporary, for rising population growth can drive increasing herd size and, eventually, rising conflicts due to over-use of farmers' fields (Bd3). 
Fig. 6. Household economy: relations between environmental, agricultural, and household economies, modeled at the field-to-commune level.

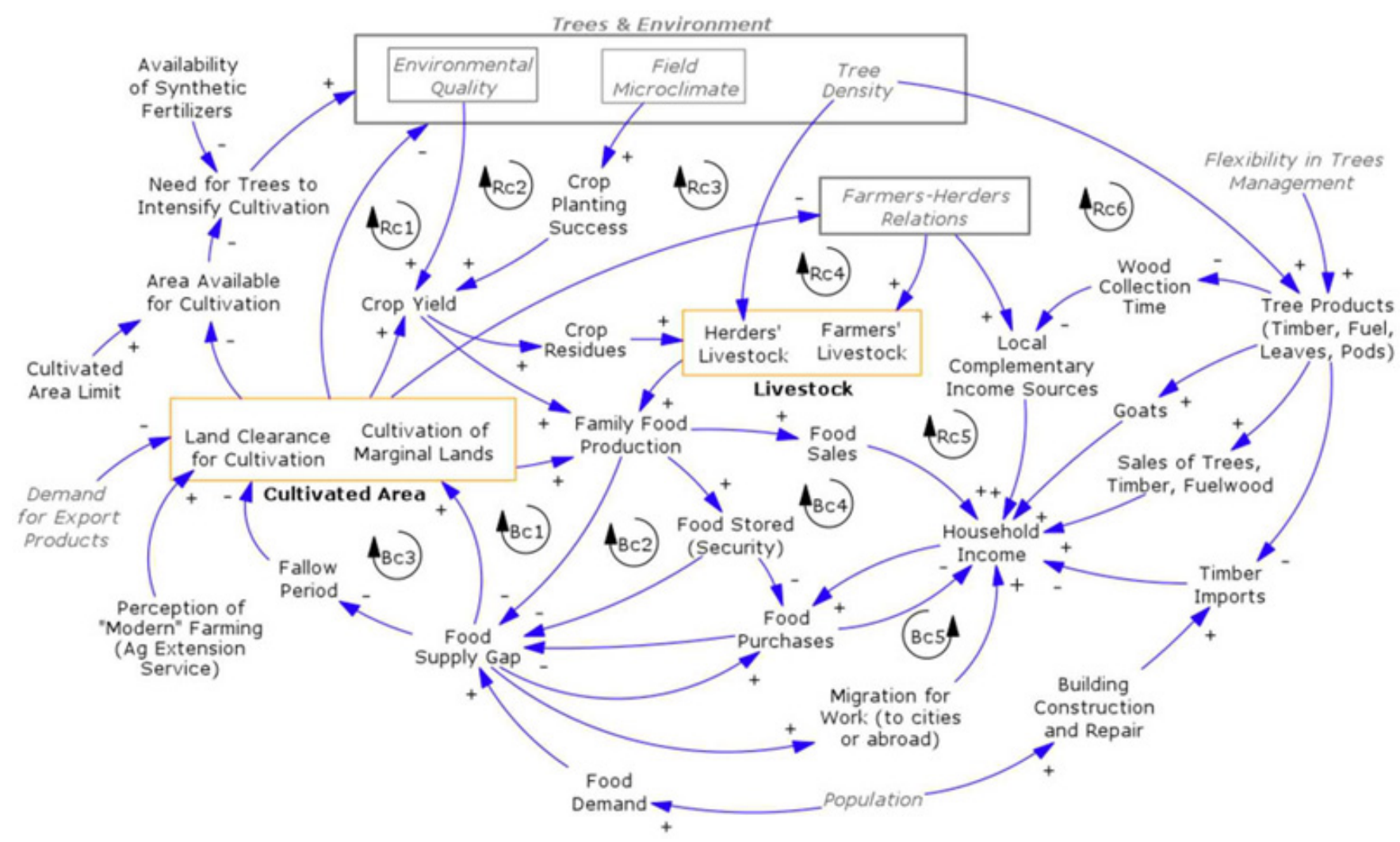

The integration of farmers' and herders' land uses within a landscape marks a swing back from the colonial dissociation of these uses into separate zones for herders (i.e., zone nomade) and farmers (i.e., zone sédentaire). This swing toward integration reflects the need to realize the mutual benefits of farmer-herder cooperation. Traditionally, farmers sought to entice herders onto post-harvest fields with gifts of money, sugar, and tea as well as by digging wells on the fields and consigning some of their livestock to herders hoping that the herder would bring the whole herd (Horowitz and Little 1987). Increased social capital (village committees) and built capital (demarcated migration corridors) have now been added to these strategies to make land uses more complementary.

With the help of international NGOs, local autonomy benefited from reengagement with the national government. The adaptive capacity of local farmers and communities to manage agro-forest landscapes increased as farmers were released from the control of corrupt or incompetent forest officers, and as farmers gained timely and appropriate support from national and international levels (Fig. 8). Both the NGO, Serving in Mission, and an IFAD project in the Aguie Department of Maradi (Tougiani et al. 2008, International Fund for Agricultural Development 2009) worked with Niger's ministry of agriculture and ministry of environment to provide programs supporting development of local social capital (Pretty and Ward 2001). These supported not only the introduction and development of farming innovations (farmer-managed natural regeneration), but also the establishment of organizations to decide on how to manage, monitor, and sanction violations of those decisions. The new organizations increased social cohesion by integrating society within and between villages. Higher integration resulted from including previously marginalized groups in decision making. Traditional authorities were also 
Fig. 7. Farmer-herder relations: relations between tree and row-crop farmers and pastoralists, modeled at local-to-regional levels.

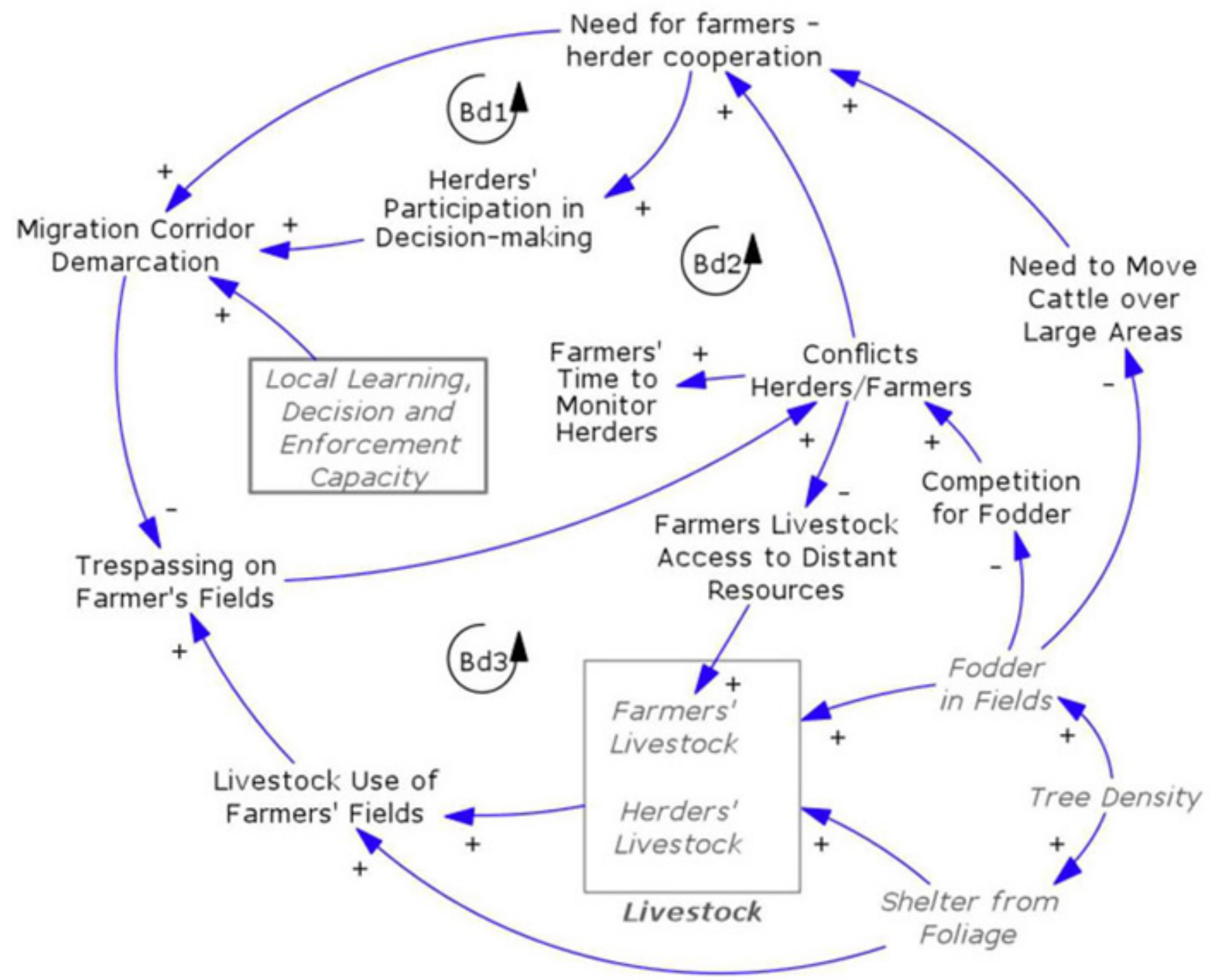

integrated within new institutional structures that reestablished a higher degree of local autonomy some 70 years after it was eliminated or minimized by colonial centralization of power. This may help to stabilize local social capital that has continued to decline in the post-colonial era with the gradual disappearance of kinship networks and tribute systems (Batterbury and Warren 2001). The local sense of autonomy continued to increase with each decision that enhanced tree cultivation and the local economy, and it more firmly erased long-standing uncertainty about who controls trees and natural resources in general. Ironically, local social capital coevolved with improved functional ties to regional and national organizations. Resilience to drought emerged not from segregating organizations at different scales but from rebuilding healthier relations within and across scales once isolation had broken the pathological dominance from the national government. 
The French colonial legacy placed control of natural resources firmly in the hands of the national government (Fig. 9). This continued while national elites were educated in France and advised by consultants operating under the paradigm of neocolonial development. However, that paradigm was undermined by the failure of export agricultural policies, or technical responses to famines, to sustain rural economies. It was further undermined by the success of new alternatives like farmermanaged natural regeneration, and the ability to enforce national policies faded with the political and economic collapse of the national regime. As the collapse of exports of peanuts (1960s) and uranium (early 1980s) deprived the national economy of significant income, only international donors and lenders provided financial support at the scale national authorities were accustomed to. These few external economic life-lines reinforced dependence on outside funds, diverting attention from the potential for local economic revival. It also deepened national authorities' dependence on the image of the Sahel in crisis, an icon that stimulated international relief efforts both during famines and afterward as part of efforts to rebuild the economy. However, eventually some of the international support was better targeted at pressuring the national government to support local self-reliance. This checked any inclination to return to central control of resources and increased national support for local development, such as collaboration with international NGOs such as Serving in Mission and the IFAD project. Institutionalizing the national commitment to local self-reliance has taken shape as formal policy, but the language of the code is ambiguous (Elbow 1996, Gado 1996) and implementation is tentative or nonexistent. The regional reach of the national government continues to be threatened by Tuareg resistance, which occasionally has flared into open rebellion in Niger as well as neighboring Mali (Hershkowitz 2005).

These six previous causal loop diagrams (Figs. 3 to 9) are not exhaustive descriptions of all factors related to tree-cover dynamics in the Maradi/Zinder region, e.g., the reference mode. They have been simplified to facilitate communication of ideas that span disciplines and scales. They trace the interactions between some of the factors that are critical to those dynamics within any one scale ( field or village or region or nation) extending sometimes across to one or more other scales, for example, from field to national levels. In Fig. 10, we distill each preceding diagram into a subset of only the most important variables and represent it as a module (outlined in orange). Relations between these modules summarize all the feedbacks that linked them at all scales in driving the reference mode, which we complement below with an overview narrative that aggregates all interactions to a macro level (national and international), following the order of reinforcing feedbacks, e.g., R1 to R6.

The decline of tree cover in Niger accelerated after 1920 when the rate of tree removal jumped far ahead of tree cultivation. This flip was driven initially by the French colonial mandate to increase crop exports through land clearance and cultivation. Colonial efforts to enhance an export economy by nationalizing natural resources stifled local social capital that had previously supported tree cultivation. By formalizing central control, trends were institutionalized as a set of reinforcing feedbacks, barriers from national (state) level, that continued to block (B3) tree cultivation with incompetent and/or corrupt enforcement. This erased local capacity to learn, decide, and enforce their own rules, leading to lawless tree removal as well as loss of knowledge about tree cultivation and to replacement of that knowledge with external paradigms about "modern", e.g., treeless, agriculture. As a result, local learning, decision and enforcement capacity, and trees and environment continued to pull each other lower as each sank (R1). Dwindling tree cover and household income reinforced the notion of people helpless to resist drought or the humiliation of external political domination. Local initiative was funneled more into migration to find work elsewhere as opposed to innovations to boost local capacity. In similar ways, other feedback loops, which previously reinforced tree cultivation, flipped from virtuous to vicious cycles, pulling down farmer-herder relations (R2), regional exchange of information (farming knowhow and seeds), and access to distant grazing resources (R3, R4, and R5) along with the rest. These downward trends were sustained by national failure to pursue local development. The history of local decline only enhanced the image of Sahel in crisis, focusing all state attention on the easiest sources of large tranches of support, i.e., international donors, as opposed to concrete and sustained programs to increase rural capacities to boost the economy. Dependence on external sources was only exacerbated by international military aid to counter regional uprisings by seminomadic groups such as the Tuareg. 
Fig. 9. National capacity to govern in Niger: relations between environmental and socio-political factors modeled at regional-to-international levels.

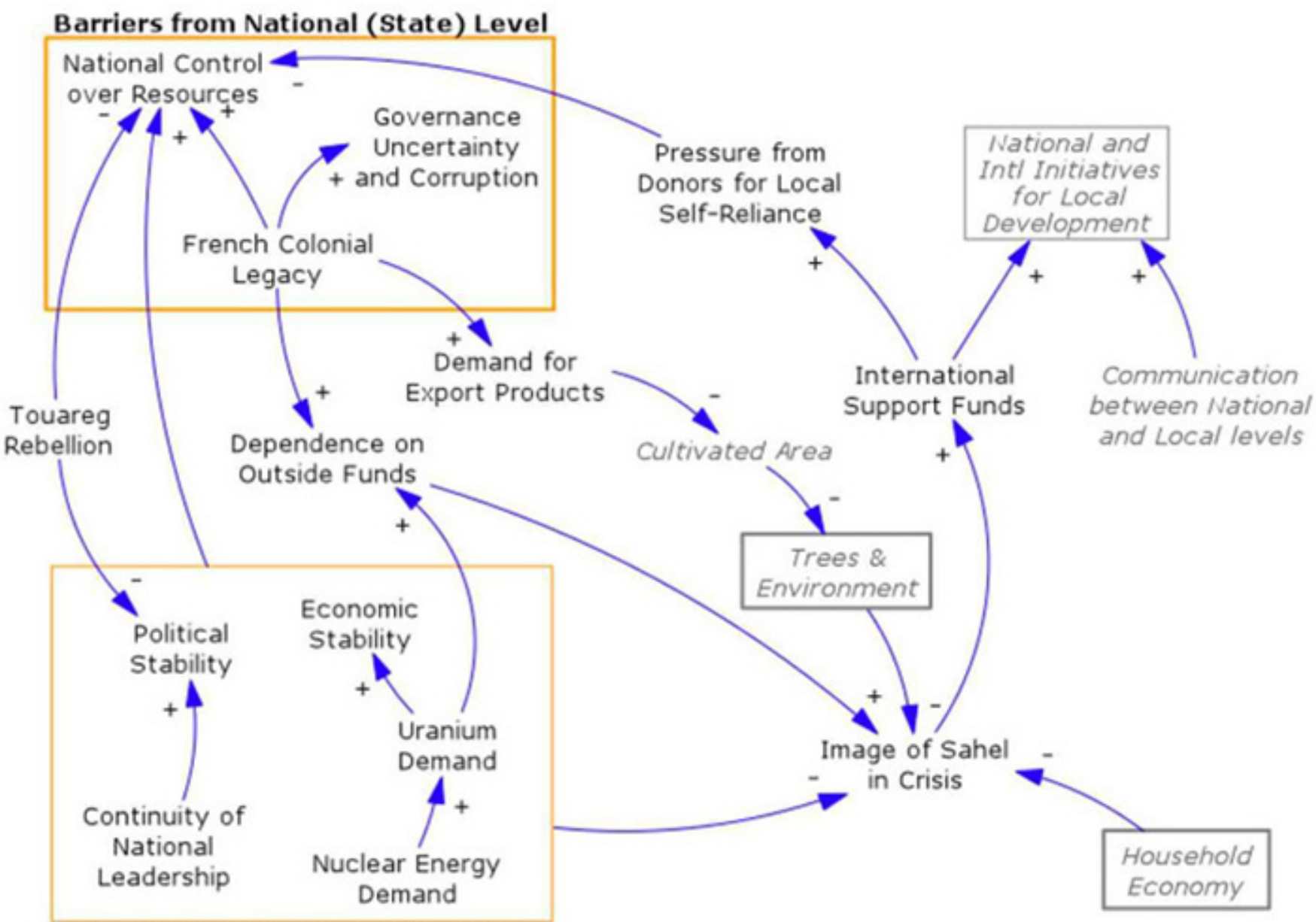

Political and Economic Stability

Droughts and famines repeatedly demonstrated how unsustainable Niger's development trajectory was, especially given a high population growth rate that increasingly diluted the resource share of each person. However, the opportunities that led to reversal of the region's downward spiral came initially from attempts to learn from the failed responses to the extreme drought of the early 1970s. At the regional level, technical experiments in tree planting and crop production enhancement failed to restore tree cover or food security and prompted international donors to pursue new avenues to boost local autonomous capacity for subsistence. This led not only to a heightened lobbying campaign to shift international and national support for local self- reliance, it also prompted a review of existing agricultural practices that eventually led to the discovery of farmer-managed natural regeneration. The former trend blunted national suppression of local autonomy (B3), and these barriers largely collapsed when state control imploded with the loss of political and economic stability. Rural Niger was effectively decoupled (van Eeten and Roe 2002) from the state capital Niamey and was free to experiment with practices that would feed Nigeriens first and earn export earnings eventually-i.e., the reverse of the neocolonial emphasis on export first followed by trickle-down of profits for local development. 
Fig. 10. General overview of ecological, economic, and social macro relationships influencing the regreening of the Sahel in Maradi Region of Niger. (Complete descriptions of the sequence of variables in each feedback loop are in Appendix 2.)

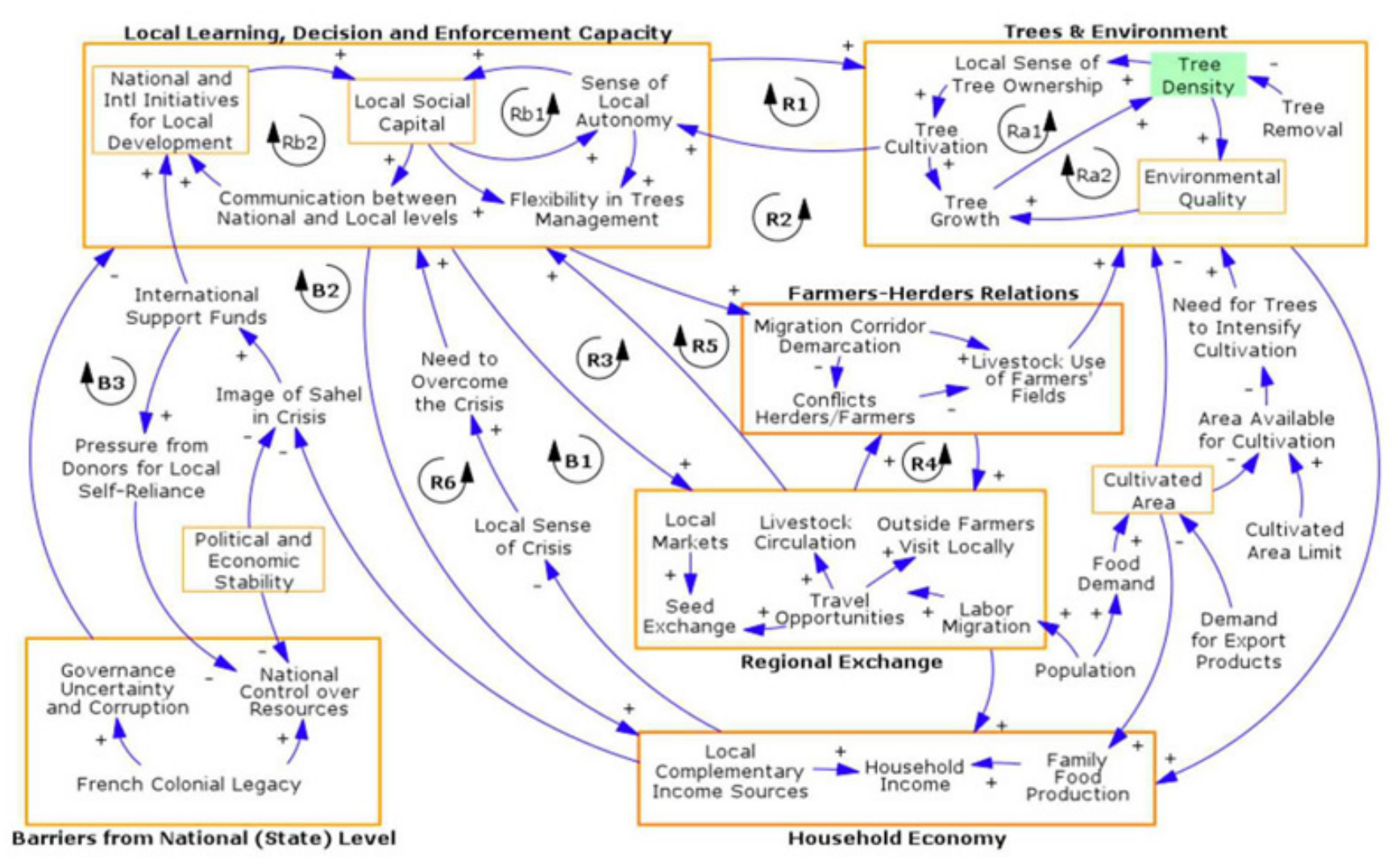

These openings at macro levels coincided with increased motivation to innovate from below, as multiple alignments created a window of opportunity for change (Kingdon 1995; Olsson et al. 2004, 2006). Within the Maradi/Zinder region, rumors of the Sahara desert smothering the region spread like an icon of doom and combined with famine (collapse of household economy) and mass migration to push the local sense of crisis past a tipping point to an unprecedented openness to try new strategies. This facilitated local collaboration in experiments in water harvesting techniques, tree cultivation, and institutionalization of local capacity to decide on their own rules and monitor and sanction farming practices. When the NGO Serving in Mission sponsored thousands of experiments with these innovations in the food-for-work program to relieve the 1985 famine, experimental success reached a critical mass to sweep across the region. Farmers noted they no longer had to replant crops three or four times when the trees cut field wind speed, and the mounting sequence of success after success in food security, profitable sales, and reduced social tension reflected the flipping of all the reinforcing feedback loops (R1 to R6) from vicious to virtuous cycles. Farmers and their communities could learn, improve, and enforce better practices (R1); count on better relations with herders to increase livestock-mediated fertilization of fields (R2); and increase their regional reach to information (R3), seeds, grazing lands, and jobs (R4 and R5). Gradually their increased autonomy and economic success eased the sense of crisis (R6).

\section{DISCUSSION}

\section{Trajectories driven by resilience dynamics}

This paper adds to a growing body of research that tests the idea that robust and sustainable policies require understanding what bridges the ecological, 
economic, and socio-political domains. We have used systems diagrams to look at the structure of feedbacks between variables from all three domains that might have influenced the regreening (e.g., tree cover dynamics) of the Nigerien Sahel. We now expand from the reference mode's dynamics of the ecological domain (tree cover) to add socio-political axes (governance and institutional capacity) and economic axes (livelihood support per capita) to Fraser's 3-space framework for examining the trajectory of the Maradi/Zinder region (Fig. 11). Specifically, we are interested to see how the resilience of social-ecological systems in the Maradi/Zinder region changed as they moved relative to these three dimensions. Movement toward the nearest lower left-hand corner reflects increasing resilience to stress and shock (such as droughts) as agro-ecosystems become more robust, as governance institutional capacity rises, and as the number of livelihood options increases. Movement to the farthest upper right-hand corner reflects declining resilience as all three domains decline.

Resilience declined initially (1900-1935) as colonial authorities weakened rural governance structures by centralizing power and started limiting the diversity and capacity of local livelihoods to support rural populations by redirecting the economy for export. The second period (19351970) accelerated these trends as all resources and institutions came under central control, and the economy was linked to growing demand from Europe's rebounding economy after World War II. Resilience declined even more steeply as the only remaining key pillar of support (agro-ecosystem integrity) was devastated by massive tree clearance for land cultivation. Even though treeless monoculture had degraded ecological integrity, the social-ecological system was sustained by high agricultural productivity during the unusually wet climate following World War II. However, the population had more than doubled since 1920, so livelihood support per capita was drawn further down.

All these declining trends were exacerbated by the extreme drought of the early 1970s. Resilience plunged to its lowest point in the third period (19701982) as famine drove massive tree clearance and livestock culls and migration. However, in the early 1980s, the declines in governance and agroecosystem integrity began to reverse, with the emergence of external pressure working on two fronts. First, the national government was urged to support local autonomy, and, second, funding and expert advice were provided to rediscover tree cultivation and reestablish local control. By the end of the third period, the seeds of new sustainable farming practices (farmer-managed natural regeneration), and the social capital to monitor and enforce them, created the potential for local communities to manage their own resources. A highly respected leader, President Kountché, helped sustain national control through the drought crisis. However his death in 1987 created a political vacuum that released local social-ecological systems from national domination or indifference. When political and economic instability reduced the state's capacity to interfere and expropriate resources, local communities could realize that potential. Resilience increased as a wave of innovation based on farmermanaged natural regeneration progressively reestablished woodland tree cover over 5 million hectares, and local communities relearned-by-doing how to successfully manage their own people and landscapes. By the drought of 2005, governance and local tree cover rapidly recovered at local levels; this recovery was reinforced by healthy links across the region mediated by herders, NGOs, and even the national government.

In contemplating the long-term sustainability of this new configuration, consider that the population is now more than six times larger than in 1920, so livelihood support per capita remains low. The options for local livelihoods have markedly increased, but the resources per capita only slightly so. And population growth continues undiminished. The Maradi/Zinder region has reestablished enough resilience to sustain itself under normal conditions, and to withstand droughts better than other Sahel regions. However, that resilience will dwindle if population levels continue to grow. Demographic flows are mostly seasonal, and distant labor sources, such as coastal West African cities or Europe, are reaching saturation, both politically as well as economically.

\section{Building a systems overview: present lessons and future research}

\section{Present lessons}

Crises can plunge society into a state of emergency whose demands for rapid communication and action provoke single-issue explanations and policies from decision makers. The narrow technical responses to 
Fig. 11. Changes in resilience of Nigerien farmers to drought in the Maradi and Zinder Regions of Niger in the twentieth century as reflected in changes in biophysical (agro-ecosystems), economic (livelihood support per capita), and social (governance) dimensions relative to one another.

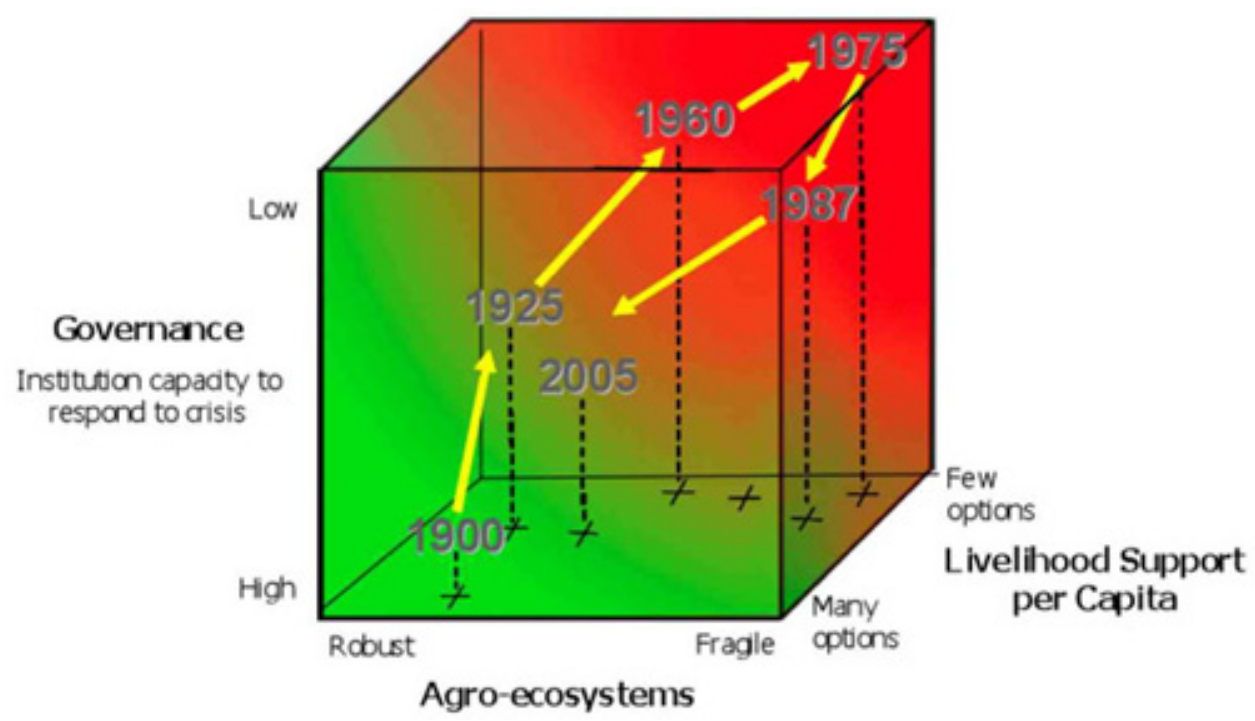

the Sahel drought emergency of the 1970s typify this tendency, and their failures highlighted the need for a broader base of understanding and policy. Systems analysis of how the system structure changed as the social-ecological system moved into and out of crisis contributes in several ways to broaden understanding. First, it shows how emphasis on one part of the system, e.g., transforming agriculture for export, eventually translated into feedbacks propagating across sectors that increased vulnerability to shock and stress, which is a classic example of policy resistance (Sterman 2000).

Systems analysis also shows why there was no single silver bullet to restore the integrity of agroecosystems or the communities that relied on them. A number of interventions at different scales and at different times combined to foster successful woodland regeneration. These ranged from the intentional, NGO-supported discovery and propagation of farmer-managed natural regeneration, to the unintentional decrease of national oversight of forestry practice in the Maradi/Zinder region. Realizing the full potential of farmer-managed natural regeneration required mutual support from multiple resources. In searching for new solutions,
NGOs built on human and social capital at local levels and integrated these with evolving human and social capital at regional and international levels. Improving relations between farmers and herders has enhanced integration at local and regional levels. It was further enhanced by improving social capital and governance at national/international levels. Coming a decade after local social capital was enhanced by the emergence of tree management oversight committees at the village and commune levels, the seeds of new forms of federal governance emerged as new national policy in response to dialogue between the national government and international organizations.

Above all, systems analysis offered the rare insight that the pattern of interactions between key resources was more important than any single resource itself. Regreening resulted not so much from introducing new technologies or new processes but from reversing the direction of reinforcing feedbacks in existing processes. Farmer-managed natural regeneration and the social capital to oversee it appear new after their antecedents faded from memory over 50 years. However, their establishment would not have been sustained and secured without multiple reversals of 
feedback loops that now reinforced each other and provided mutual support within and across all scales.

Finally, while our understanding has not progressed so far as to express interactions mathematically, we can explore the dynamics of resilience qualitatively using the Fraser conceptual framework. Two patterns emerge. First, displacement from extremes of high and low resilience begins with changes in governance, followed closely afterward by economic changes (diversity of livelihood support). Biophysical changes to agro-ecosystems trailed both governance and livelihood changes, which explains the second pattern: hysteresis. Change (deforestation) was profound in the Sahel but not irreversible - though it took prodigious efforts by hundreds of thousands of people over two decades to achieve this reversal. Significant investments (or disinvestments) in governance and livelihoods must be sustained before change in the reference mode becomes evident. However, once biophysical change begins then the other dimensions shift rapidly, suggesting that it enhances the political and social changes that started the trend. Woodland decline only reinforced centralization of power and local economic decline, and regreening sped power decentralization and local economic revival. The fact that resilience's loss preceded its reestablishment in a more desirable configuration for Sahelian social-ecological systems underscores a key point: resilience is a property to be managed, not a good to be strengthened and preserved. Managing resilience may involve lowering the resilience of undesirable social-ecological system states so as to establish better system configurations before building the resilience of a more desirable state (Folke 2006, Walker et al. 2006, Sendzimir et al. 2007).

\section{Future directions for research}

Any systematic overview of the Sahel regreening must respect the region's extreme heterogeneity. Mortimer and Adams (2001) caution that the effects of the drought were far from universal-some farmers actually succeeded in increasing production and herds during the crises of the 1970s and 1980s. The regional scale of woodland restoration suggests that dominant factors (rainfall as well as reform of practices and institutions) reinforce a regreening trend that, for the moment, is robust to local exceptions. However, at such scales, one must assume that not all factors are accounted for. Five factors clearly deserve more attention for extending this analysis to examine the resilience of the Maradi/ Zinder region in the future at international, regional, and local scales: demographics, urbanization, regional markets, institutional memory, and local farmer's coping and adaptation strategies.

The sustainability of the Maradi/Zinder region depends in part on seasonal migration. As a result of intra-regional migration, population density seasonally declines around $25 \%$ (with estimates ranging as high as 50\% (Cour 2001)), though the influence on the Maradi/Zinder region of migration out of Africa is not known. However, migration may become a less viable strategy if historic reception centers (regional African cities, Europe) reach saturation. Annual arrival of 1 million African migrants in Europe (Choe 2007) has raised political tensions that may swing policies towards exclusion, especially in times of economic contraction. How long will migration relieve the pressure of one of the fastest growing populations on Earth?

Urbanization may prove to support regional agriculture after it initially endangered it. Colonial development of livestock watering points and urban centers intensified resource demands on surrounding lands to the point where desertification first became apparent around them (Walter 1952). However, expansion of a secondary tier of regional cities might finally provide the regional markets that could sustain Sahel farmers and lower their dependence on export markets (Cour 2001). If this happened, then it may provide enough income diversification to better sustain household livelihoods (Bryceson 2002). This point was noted by Cour (2001) who argued: "The distribution of the rural population is more and more determined by the size and location of urban markets and by infrastructure. Rural population density, output per hectare (yield) and output per rural inhabitants (agricultural productivity) correlate well with market attractiveness."

Farmers and pastoralists responded far faster and with greater skill to the 1985 drought than to the preceding one in the early 1970 s. For example, in 1985 the herders moved herds much sooner to less arid southern zones in 1985. One reason might be that the lessons of the 1970s drought still lingered in the 1980s, but the coping skills honed in the 19401944 drought may have faded by 1969 . This suggests that the extraordinary skill base required to respond to severe droughts will erode over time 
Table 1. Crises and farmers' strategic adaptations in the Sahel, after Mortimer and Adams (2001).

\begin{tabular}{ll}
\hline \hline Perception of 'crisis' & Strategic adaptations by farmers \\
\hline Drought & $\begin{array}{l}\text { Negotiating the rain } \\
\text { - Adapting timing and quantity of labor to rainfall pattern. } \\
\text { Food }\end{array}$ \\
Managing biodiversity \\
- Maintain stocks of locally adapted edible plant varieties. \\
Stocking & $\begin{array}{l}\text { Integrating animals } \\
\text { - Sustain livestock herds as self-reproducing assets that integrate natural variability. }\end{array}$ \\
Environmental degradation & $\begin{array}{l}\text { Work land harder } \\
\text { - Mobilize labor to work with livestock to intensify production. }\end{array}$ \\
Coping & $\begin{array}{l}\text { Diversifying livelihoods } \\
\text { - Diversify ownership (livestock) and income-generating activities. }\end{array}$ \\
\hline
\end{tabular}

unless "pumped" by droughts often enough to overcome memory loss. This raises several questions. Were the rate and extent of memory loss influenced during the colonial and neocolonial periods by shifts in farming and forestry policy and practice, and by the paradigms underlying them? Could such loss be slowed or stopped in the future by institutionalizing the special skill base?

Much work remains to be done to understand how social capital functions at household and village levels to help families "negotiate their way through the hierarchy of coping strategies" (Mortimer and Adams 2001). Furthermore, given the potential for skillful interventions by international NGOs and for national policy reform, will local social capital coevolve with institutions and governance at national and international levels? At local levels, families cope with crisis by negotiating the allocation of household labor in three sequential steps: livestock ownership, business (trade, manufacture, services), and outside activities (for social, political, or religious reasons, and for income). Such diversification of livelihoods is but one rung in a larger ladder of adaptive responses (Table 1) triggered by how the crisis is perceived. Further systems analysis should examine how such family adaptations fit into the processes and institutions operating at the field, village, landscape, regional, and national levels.

\section{CONCLUSIONS}

Two development trajectories appeared in Niger in the twentieth century, each catalyzed by a different kind of foreign intervention. The colonial intervention uncritically applied a European export model to the entire Sahel region, thus totally reforming the landscape, institutions, and the practices of agriculture and forestry. It succeeded during relatively wet periods to generate wealth at the cost of increased vulnerability to episodes of drought and famine, especially for millions of rural farmers and pastoralists. When wholesale imposition of ideas conceived outside of Niger was abandoned, then a second, more sustainable, trajectory emerged. Interventions began exploring with people at all levels of Nigerien society for what sustains production as well as the ecosystems and society that support it. The regreening of the Maradi/ Zinder region provided biophysical evidence (200 million trees), economic evidence (thriving livelihoods), and social evidence (enhanced social capital and reduced conflict) that the second development trajectory is more sustainable across all sectors of society. In wet periods livelihoods in the Maradi/Zinder region could flourish enough to sustain people locally as well as sustain export for profit. During the most recent drought the region suffered far less than any other part of Niger.

Few of these facts are new. But systems analysis helped to integrate these facts into a new synthesis 
that supports some existing hypotheses and adds novel insights to explain both previous failures and the current success in reforesting the Maradi/Zinder region. It legitimates the drive in sustainability science to develop an interdisciplinary conceptual framework for assessing vulnerability (Turner et al. 2003, but see Patt et al. 2009) by revealing how interactions across the biophysical, economic, and social domains were critical to regreening success. The failure of single-issue policies becomes more understandable when one recognizes that the pattern of interactions was more important to the sustained success of regreening than any single factor or process. Interventions at different scales catalyzed the shift from vicious to virtuous circles, and it is this multilayered pattern of reinforcement that has sustained regreening. These new patterns of interactions improved and sustained livelihoods and ecosystems in the Maradi/Zinder region such that they coped with the latest drought better than any other region of Niger. However, while they seem better at coping with economic or climatic shock or stress, the resilience of society and nature in the Maradi/Zinder region to global sources of uncertainty remains a pressing question in a society with one of the highest population growth rates on Earth.

Responses to this article can be read online at:

http://www.ecologyandsociety.org/voll6/iss3/art1/responses/

\section{Acknowledgments:}

We are grateful for the insightful comments of two anonymous reviewers who generously shared their considerable experience in the Sahel to help improve this paper. In addition, the text and supporting materials benefited from the critical advice of Gray Tappan.

\section{LITERATURE CITED}

Anderson, J., A. Shaikh, C. Barrett, P. Veit, J. Ribot, R. Winterbottom, M. McGuahey, and R. Hagen. 2002. Nature, wealth and power: emerging best practice for revitalizing rural Africa. United States Agency for International Development (USAID), Washington, D.C., USA.
Batterbury, S., and A. Warren. 2001. The African Sahel 25 years after the great drought: assessing progress towards new agendas and approaches. Global Environmental Change 11(1):1-8.

Boyd, C., and T. Slaymaker. 2000. Re-examining the 'more people less erosion' hypothesis: special case or wider trend? Natural Resources Perspectives No .63, The Overseas Development Institute (ODI), London, UK.

Brough, W. T., and M. S. Kimeny. 2004. "Desertification" of the Sahel: exploring the role of property rights. PERC Reports (Property and Environment Research Center) 22(2):15-17. Special Issue: Africa.

Bryceson, D. F. 2002. The scramble in Africa: reorienting rural livelihoods. World Development 30(5):725-739.

Buerkert, A., and P. Hiernaux. 1998. Nutrients in the West African Sudano-Sahelian zone: Losses, transfers and role of external inputs. Zeitschrift fuer Pflanzenernaehrung und Bodenkunde 161:365-383.

Central Intelligence Agency. 2008. The world factbook, Africa, Niger. Washington, D.C., USA. [online] URL:https://www.cia.gov/library/publications/ the-world-factbook/geos/ng.html\#People

Choe, J. 2007. African migration to Europe. Council on foreign relations backgrounder. [online] URL: http://www.cfr.org/publication/13726/ african migration to europe.html

Clark, W.C., and N. Dickson. 2003. Sustainability science: the emerging research program. PNAS 100 (14): 8059-8061.

Comité permanent Inter-Etats de Lutte contre la Sécheresse dans le Sahel (CILSS). 2005. The Sahel: growing green again, a scientific assessment of 20 years of desertification control in Niger. Permanent Inter-State Committee for Drought Control in the Sahel, Ouagadougou, Burkina Faso. Brochure. [online] URL:http://www.cilss.bf/doc/Quand le S ahel reverdit version En.pdf

Cour, J. M. 2001. The Sahel in West Africa: countries in transition to a full market economy. Global Environmental Change 11:31-47. 
Cunningham, P. J., and T. Abasse. 2005. Annex 10: reforesting the Sahel: farmer managed natural regeneration. Pages 75-80 in A. Kalinganire, A. Niang, and A. Kone, editors. Domestication des espèces agroforestières au Sahel: situation actuelle et perspectives. Working Paper. World Agroforestry Centre, Nairobi, Kenya.

Descola, P. 1986. La nature domestique. Symbolisme et praxis dans l'écologie des Achuars. Editions de la Maison des Sciences de l'Homme, Paris, France.

Dougill, A. J., E. D. G. Fraser, and M. S. Reed. 2010. Anticipating vulnerability to climate change in dryland pastoral systems: using dynamic systems models for the Kalahari. Ecology and Society 15 (2):17. [online] URL: http://www.ecologyandsociety. org/vol15/iss2/art17/

Elbow, K. M. 1996. Legislative reform, tenure, and natural resources management in Niger: the new rural code. Land Tenure Center, University of Wisconsin, Madison, Wisconsin, USA.

Foley, J. A., M. T. Coe, M. Scheffer, and G. Wang. 2003. Regime shifts in the Sahara and Sahel: interactions between ecological and climatic systems in northern Africa. Ecosystems 6:524-539.

Folke, C. 2006. Resilience: the emergence of a perspective for social-ecological systems analyses. Global Environmental Change 16:253-267.

Fraser, E. D. G. 2007. Travelling in antique lands: studying past famines to understand present vulnerabilities to climate change. Climate Change 83:495-514. http://dx.doi.org/10.1007/s10584-007$\underline{9240-9}$

Furber, A. H. 1997. Fulani and Zarma tribes pushed into fights by desertification? TED Conflict Studies, Case No. 29. Mandala Projects, Trade and Environment Database (TED), Inventory of Conflict and Environment (ICE). American University, The School of International Service, Washington, D.C., USA. [online] URL: http://www .american.edu/ted/ice/niger.htm

Gado, B. A. 1996. Le code rural au Niger: une réforme prometteuse, une application difficile. Pages 120-124 in P. Mathieu, P. J. Laurent, and J.C. Wilame, editors. Démocratie, enjeux fonciers et pratiques locales en Afrique: conflits, gouvernance et turbulences en Afrique de l'Ouest et centrale. Cahiers Africains/Afrika Studies 23/24. Institut Africain-CEDAF, Brussels, Belgium.

Gonzalez, P., C. J. Tucker, and H. Sy. 2007. A climate change threshold for forest dieback in the African Sahel. Abstract \#B53E-03. American Geophysical Union, Fall Meeting 2007.

Grolier Multimedia Encyclopedia, (C2000 Grolier Interactive Inc.

Herrmann, S. M., A. Anyamba, and C. J. Tucker. 2005. Recent trends in vegetation dynamics in the African Sahel and their relationship to climate. Global Environmental Change 15(4):394-404.

Hershkowitz, A. 2005. The Tuareg in Mali and Niger: the role of desertification in violent conflict. TED Conflict Studies, Case No. 151. Mandala Projects, Trade and Environment Database (TED), Inventory of Conflict and Environment (ICE). American University, The School of International Service, Washington, D.C., USA. [online] URL: http://www.american.edu/ted/ice/tuareg.htm

Higgott, R. 1980. Structural dependence and decolonisation in a West African land-locked state: Niger. Review of African Political Economy 7 (17):43-58.

Holmes, J. A. 2008. How the Sahara became dry. Science 320(5877):52-753.

Horowitz, M. M., and P. D. Little. 1987. African pastoralism and poverty. Pages 59-82 in Michael H. Glantz, editor. Drought and Hunger in Africa. Cambridge University Press, Cambridge, UK.

International Fund for Agricultural Development (IFAD). 2009. Sahelian Areas Development Fund Programme. Rome, Italy. [online] URL: http://oper ations.ifad.org/web/ifad/operations/country/project/ tags/mali/1089/project\%20overview

Kerr, R. A. 1998. The Sahara is not marching southward. Science 281(5377):633-634.

Kingdon, J. W. 1995. Agendas, alternatives, and public policies. Harper Collins, New York, New York, USA.

Koechlin, J. 1997. Ecological conditions and degradation factors in the Sahel. Pages 12-36 in C. 
Raynaut, editor. Societies and Nature in the Sahel. SEI Global Environment and Development Series, Routledge, London.

Krebs, J., and M. J. Coe. 1985. Sahel famine: an ecological perspective. Nature 317:13-14.

Lahmeyer, J. 2006. Population statistics-Nigerhistorical demographical data of the whole country. [online] URL: http://www.populstat.info/Africa/nigerc. $\underline{\mathrm{htm}}$

Lamprey, H. F. 1975. Report on the desert encroachment reconnaissance in northern Sudan, 21 October to 10 November 1975. UNESCO/UNEP, Paris, France and Nairobi, Kenya. Republished in Desertification Control Bulletin 17:1-7.

Larwanou, M., M. Abdoulaye, and C. Reij. 2006. Etude de la regeneration naturelle assistée dans la Région de Zinder (Niger): une première explorartion d'un phénomène spectaculaire. International Resources Group for the US Agency for International Development, Washington, D.C., USA.

Lebel, T., Ali, A. 2009. Recent trends in the central and western Sahel rainfall regime (1990-2007). Journal of Hydrology 375(1-2):52-64.

Leblanc, M., G. Favreau, S. Massuel, S. Tweed, M. Loireau, and B. Cappelaere. 2008. Land clearance and hydrological change in the Sahel: SW Niger. Global and Planetary Change 61(3-4):135-150.

Leenders, J. K. 2006. Wind erosion control with scattered vegetation in the sahelian zone of Burkina Faso. Tropical Resource Management Papers No.73. Wageningen Agricultural University, The Netherlands. [online] URL: http://edepot.wur.nl/11 $\underline{6540}$

L'Hote, Y., G. Mahé, B. Somé, and J. P. Triboulet. 2002. Analysis of a Sahelian annual rainfall index from 1896 to 2000; the drought continues. Hydrological Sciences Journal/Journal des Sciences Hydrologiques 47(4):563-572. http://dx.d oi.org/10.1080/02626660209492960

MacDonald, L. H. 1986. Chapter 1, The Sahel: human and environmental overview. Natural Resources Development in the Sahal: The Role of the United Nations System. United Nations University Press, Tokyo, Japan. [online] URL: http
://archive.unu.edu/unupress/unupbooks/80422e/80422E02. $\underline{\mathrm{htm}}$

McGahuey, M., and B. Winterbottom. 2007. Transformational development in Niger. PowerPoint presentation. [online] URL: http://www.frameweb. org/adl/en-US/2803/file/336/Niger.pdf

McIntosh, R. 1993. The pulse model: genesis and accommodation of specialization in middle Niger. Journal of African History 34:181-220.

Mortimer, J., and W. M. Adams. 2001. Farmer adaptation, change and 'crisis' in the Sahel. Global Environmental Change 11(1):49-57.

Murton, J. 1999. Population growth and poverty in Machakos district, Kenya. The Geographical Journal 165(1):37-38.

Ngaido, T. 1995. Making laws and building institutions in the Sahel: the case of Niger. Entwicklung und Ländlicher Raum 6:19-22.

Ngaido, T., and M. Kirk. 1999. Collective action, property rights and devolution of rangeland management: selected examples from Africa and Asia. Pages 147-81 in R. Meinzen-Dick, A. Knox, and M. Di Gregorio, editors. Collective action, property rights and devolution of natural resource management: exchange of knowledge and implications for policy. Deutsche Stiftung für internationale Entwicklung (DSE), Feldafing, Germany.

Nicholson, S.E. 1983. Sub-Saharan rainfall in the years 1976-1980: Evidence of continued drought. Mon. Wea. Rev. 111: 1646-1654.

Nicholson, S. E., C. J. Tucker, and M. B. Ba. 1998. Desertification, drought, and surface vegetation: an example from the West African Sahel. Bulletin of the American Meteorological Society 79(5):815-829. http://dx.doi.org/10.1175/1520-0477(1998)079<0815: DDASVA $>2.0 . C O ; 2$

Olsson, L., L. Eklundhb, and J. Ardo. 2005. A recent greening of the Sahel: trends, patterns and potential causes. Journal of Arid Environments 63:556-566.

Olsson, P., C. Folke, and T. Hahn. 2004. Socialecological transformation for ecosystem management: the development of adaptive co-management of a wetland landscape in southern Sweden. Ecology 
and Society 9(4):2. [online] URL: http://www.ecolo gyandsociety.org/vol9/iss4/art2/

Olsson, P., L. H. Gunderson, S. R. Carpenter, P. Ryan, L. Lebel, C. Folke, and C. S. Holling. 2006. Shooting the rapids: navigating transitions to adaptive governance of social-ecological systems. Ecology and Society 11(1):18. [online] URL: http:/ /www.ecologyandsociety.org/vol11/iss1/art18/

Patt, A., D. Schröter, R. J. T. Klein, and A. C. de la Vega-Leinert (editors). 2009. Assessing vulnerability to global environmental change: making research useful for adaptation decision making and policy. Earthscan, London, UK.

Posthumus, B. 2000. Niger: a long history, a brief conflict, an open future. European Centre for Conflict Prevention, The Hague, The Netherlands.

Pretty, J., and H. Ward. 2001. Social capital and the environment. World Development 29(2):209-227.

Raynaut, C. 1997. Societies and nature in the Sahel. SEI Global Environment and Development Series, Routledge, London.

La Recherche Agronomique pour le développement (CIRAD). 2005. After the famine in Niger: how can we fight food insecurity in the Sahel? French Agricultural Research Centre for International Development, Paris, France.

Reij, C. 2006. More success stories in Africa's drylands than often assumed. Conference Proceedings, Forum sur la Souveraineté Alimentaire, Niamey, 7-10 novembre 2006. Reseau des Organisations Paysannes et de Producteurs Agricoles de l'Afrigue de l'Ouest (ROPPA), Ouagadougou, Burkina Faso.

Reij, C., G. Tappan, and M. Smale 2009. Agroenvironmental transformation in the Sahel: another kind of "green revolution". IFPRI Discussion Paper 00914. International Food Policy Research Institute, Washington, D.C., USA.

Rinaudo, T. 2001. Utilizing the underground forest: farmer managed natural regeneration of trees. Pages 325-336 in D. Pasternak and A. Schlissel, editors. Combating Desertification with Plants. Kluwer Academic/Plenum Publishers, New York, New York.
Scherr, S. J., and S. Sthapit. 2009. Mitigating climate change through food and land use. World Watch Report 179. World Watch Institute, Washington, D.C., USA.

Scoones, I., and W. Wolmer (editors). 2002. Pathways of change in Africa: crops, livestock and livelihoods in Mali, Ethiopia and Zimbabwe. Institute of Development Studies, London, UK.

Sendzimir, J., P. Magnuszewski, Z. Flachner, P. Balogh, G. Molnar, A. Sarvari, and Z. Nagy. 2007. Assessing the resilience of a river management regime: informal learning in a shadow network in the Tisza River Basin. Ecology and Society 13 (1):11. [online] URL: http://www.ecologyandsociety. org/vol13/iss1/art11/

Senge, P.M.1992. The fifth Discipline: the art and practice of the learning organization. Doubleday, New York, New York, USA. http://dx.doi.org/10.1 $\underline{002 / p f i .4170300510}$

Sheil, D., and D. Murdiyarso. 2008. How forests attract rain: an examination of a new hypothesis. BioScience 59(4):341-347. http://dx.doi.org/10.1525/ bio.2009.59.4.12

Soumare, A. 1995. Utilisation des éléments nutritifs par deux arbres du Sahel: Acacia seyal et Sclerocarya birrea. Dissertation. Institut Superieur de Formation à la Recherche, Bamako, Mali.

Sterman, J. 2000. Business dynamics: systems thinking and modelling for a complex world. McGraw-Hill, Boston, Massachusetts, USA. 
Sterman, J. 2002. All models are wrong: reflections on becoming a systems scientist. System Dynamics Review 18(4):501-531

Swinton, S. M. 1988. Drought survival tactics of subsistence farmers in Niger. Human Ecology16 (2):124-144.

Tappan, G., and M. Cushing. 2004. Use of SLC-Off Landsat image data for monitoring land use / land cover trends in West Africa. U.S. Geological Survey (USGS), Earth Resources Observation and Science (EROS) Data Center, Sioux Falls, South Dakota, USA.

Tappan, G., and M. Cushing. 2008. Experiences of mapping land use and land cover and deriving trends over the vast West African region. Conference presentation, U.S. Geological Survey (USGS), Reston, USA. [online] URL: http://www.oosa.unvi enna.org/pdf/sap/2008/graz/presentations/05-01.pdf

Thébaud, B., and S. Batterbury. 2001 Sahel pastoralists: opportunism, struggle, conflict and negotiation. A case study from eastern Niger. Global Environmental Change 11(1):69-78.

Tiffen, M., M. Mortimore, and F. Gichuki. 1994. More people, less erosion: environmental recovery in Kenya. Land Degradation \& Development 11 (2):111-124.

Tougiani, A., C. Guero, and T. Rinaudo. 2008. Community mobilization for improved livelihoods through tree crop management in Niger. GeoJournal 74(5):377-389. doi 10.1107/

s10708-008-9228-7

Tucker, C. J., H. E. Dregne, and W. W. Newcomb. 1991. Expansion and contraction of the Sahara desert from 1980 to 1990. Science 253 (5017):299-300.

Turner, B. L. II, R. E. Kasperson, P. A. Matson, J. J. McCarthy, R. W. Corell, L. Christensen, N. Eckley, J. X. Kasperson, A. Luers, M. L. Martello, C. Polsky, A. Pulsipher, and A. Schiller. 2003. Science and technology for sustainable development special feature: a framework for vulnerability analysis in sustainability science. Proceedings of the National Academy of Sciences of the United States of America, Special Feature 100(14)(8 July):8074-8079. doi:10.1073/pnas.1231335100
United Nations Disaster Relief Organization (UNDRO). 1985. Niger drought. UNDRO Situation Report. UNDRO, Geneva, Switzerland.

United States Agency for International Development (USAID). 1989. Sahel Development Program: 1986-1988; Report to Congress. Agency for International Development, Washington, D.C., USA.

United States Agency for International Development (USAID). 2005a. Niger-drought and locusts. Situation Report No. 1. Washington, D.C., USA.

United States Agency for International Development (USAID). 2005b. Niger-food insecurity. Situation Report No. 2. Washington, D.C., USA.

van Eeten, M .J. G., and E. Roe. 2002. Ecology, engineering and management: reconciling ecosystem rehabilitation and service reliability. Oxford University Press, New York, New York.

von Braun, J., T. Teklu, and P. Webb. 1999. Famine in Africa: causes, responses, and preventions. Food Policy Statement No. 28. International Food Policy Research Institute (IFPRI), Washington, D.C., USA. [online] URL: http://www.ifpri.org/pubs/FPS/ fps $28 . h$ tm

Walker, B. H., L. H. Gunderson, A. P. Kinzig, C. Folke, S. R. Carpenter, and L. Schultz. 2006. A handful of heuristics and some propositions for understanding resilience in social-ecological systems. Ecology and Society 11(1):13. [online] URL: http://www.ecologyandsociety.org/vol11/iss 1/ $\underline{\operatorname{art} 13 /}$

Walter, H. 1952. Management and conservation of vegetation in Africa (Nutzung und Erhaltung der Vegetation in Afrika), a symposium. Bulletin No. 41 of the Commonwealth Bureau of Pastures and Field Crops, Penglais, Aberystwyth, Wales. Commonwealth Agricultural Bureaux, Farnham Royal, Bucks, England. Zeitschrift für Pflanzenernährung, Düngung, Bodenkunde 57:171-172. doi: 10.1002/ jpln.19520570214

Wellard, K., and M. Mortimore. 2000. Farmer-led adoption of ox weeding in Machakos District, Kenya. Pages 232-234 in P. Starkey and T. Simalenga, editors. Animal power for weed control, a resource book of the Animal Traction Network for Eastern and Southern Africa (ATNESA). Technical 
Centre for Agricultural and Rural Cooperation (CTA), Wageningen, The Netherlands.

Wezel, A., B. Bohlinger, and R. Böcker. 2008. Vegetation zones in Niger and Benin-present and past zonation. In L. Herrmann, editor. Atlas of natural and agronomic resources of Niger and Benin. University of Hohenheim, Stuttgart, Germany.

Wickens, G. E. 1997 Has the Sahel a future? Journal of Arid Environments 37(4):649-663.

World Resources Institute (WRI). 2006. Agriculture and food, country profile-Niger. Washington, D.C., USA. [online] URL: http://earthtrends.wri.org/text/ agriculture-food/country-profile-136.html

World Resources Institute. 2008. World Resources 2008-roots of resilience: growing the wealth of the poor-ownership, capacity, connection. World Resources Report. World Resources Institute (WRI), Washington, D.C., USA, in collaboration with United Nations Development Programme, and World Bank. [online] URL: http://pdf.wri.org/worl d resources 2008 roots of resilience.pdf

Zanini, M. 2009. "Power curves": what natural and economic disasters have in common. McKinsey Quarterly June 2009. McKinsey \& Company, New York, USA. 
APPENDIX 1. System Dynamics diagram protocols

\section{System Dynamics notation:}

System dynamics diagrams are designed to help overcome the frequent tendency to default to linear assumptions about causation. These diagrams, sometimes known as causal loop diagrams, do this by helping us trace more complex patterns of causation: circles and webs. Causal loop diagrams are arranged so as to communicate complex patterns better by eliminating clutter and overlapping arrows and by achieving some measure of symmetry so that it is easy for the eye to follow paths of 'causation,' such as around loops or across webs. Thus feedback loops may be clockwise or counterclockwise for stylistic reasons, but the influence of the loop on dynamics is mostly related to whether it is a reinforcing or balancing loop by itself and as to how it is structurally linked to other loops that may counter or reinforce its actions. Following the System Dynamics protocol, arrows denote a relation between two variables. A (+) polarity indicates that both change in the same direction, e.g., if one increases the other tends to increase as well. A (-) polarity indicates that when one changes in value the other tends to change in the opposite direction. Feedback loops are distinguished by the letter R (reinforcing) and B (balancing). Change will continue in the same direction by the time a circuit is made all the way around a reinforcing feedback loop. That means that increase in one variable in a reinforcing feedback loop will end up increasing even further by the chain of interactions going all the way around the loop, and a decrease would also be augmented by completing the circuit. By contrast, the direction of change will be reversed by completing a circuit around a Balancing Feedback loop. So an increase in one variable will eventually be translated into a decrease of that variable when the chain of interactions goes all the way back to the point of origin. For example, in Fig. 7,the loop Bd1 is balancing because the polarities +-++ end up reversing the initial change by the end of the loop. Try reading the polarities as words, then the series becomes: same(+), different(-), same(+), same $(+)$. 
APPENDIX 2. Feedback loop sequences in Fig. 10

B1: Local Sense of Crisis Need to Overcome the Crisis Local Learning Decision and Enforcement Capacity Trees \& Environment Local Development Local Sense of Crisis;

B2: Trees \& Environment Local Development Image of Sahel in Crisis International Support Funds National and Intl Initiatives for Local Development Local Learning, Decision and Enforcement Capacity Trees \& Environment;

B3: Trees \& Environment Local Development Image of Sahel in Crisis International Support Funds Pressure from Donors for Local Self-Reliance National Control over Resources Local Learning, Decision and Enforcement Capacity Trees \& Environment;

R1: Tree Cultivation Sense of Local Autonomy Trees \& Environment Tree Cultivation:

R2: Tree Cultivation Sense of Local Autonomy Farmers-Herders Relations Environmental Quality Tree Cultivation;

R3: Regional Exchange Local Learning, Decision and Enforcement Capacity Regional Exchange;

R4: Regional Exchange Farmers-Herders Relations Regional Exchange; R5: Regional Exchange Local Learning, Decision and Enforcement Capacity Farmers-Herders Relations Regional Exchange;

R6: Local Development Local Sense of Crisis Need to Overcome the Crisis Local Learning, Decision and Enforcement Capacity Local Development;

R7: Tree Density Local Sense of Tree Ownership Tree Cultivation Tree Growth Tree Density;

R8: Tree Density Environmental Quality Tree Growth Tree Density;

R9: Sense of Local Autonomy Local Social Capital Sense of Local Autonomy;

R10: National and Intl Initiatives for Local Development Local Social Capital Communication between National and Local levels 
APPENDIX 3. Chronology of twentieth Century Political, Economic and Environmental Events in Niger (References in parentheses are listed at bottom)

\section{Period Events}

1890s Colonial expansion - French military force defeats all tribal military forces.

Initial formalization of contacts - French signed treaties with the rulers of the Say, Gaya, and Dosso states. (1) (2)

$1900-1920$ s French policy shifts Niger agriculture export away from traditional trans-Sahara trade toward international export through East-West trade through Atlantic ports to Europe (3)

$1913-14$

1916-17

Famine as a result of a locust outbreak (6)

Tuareg uprising as a result of a famine, a harsh tax regime and the French recruitment drive for its troops (8)

Niger formally incorporated as a French colony in French West Africa (1)

1920s French launch three prong development scheme for "evitalization to counter signs of stagnation under the new export regime - Increase number of wells, veterinary and medical campaigns, open markets to South (3)

1930s Environmental degradation emerges as surprising reaction to revitalization campaign (3)

- Overgrazing and Deforestation no clear property rights regarding vastly expanded well network exploited by expanding human and cattle populations

1931-32 - Population increase (human and livestock) med and vet campaigns, and herds not sold for export as they are a sign of wealth.

Famine as a result of a locust outbreak (6)

1935 Nationalization of all natural resourcesFrance establishes national law for Niger that asserts state control over all natural resources, including trees (3) (4)

1950 - 1960s Above average rainfall supports an increasing agricultural export economy and enables Haussa farmers to migrate northwards and settle in lower rainfall areas

1971-73 Famine as a result of a Intense drought (7)

1970s Large-scale application of technical solutions to address drought threat and improve food security

- $\quad$ Reforestation with exotics (20\% of 60 million trees survive).

- CARE International's Majjia Valley Project (4)

1980s- Internationally-based NGO (Serving In Mission)

- Identifies potential to nurture existing shrubs to trees, formalizes it as a set of practices (farmermanaged natural regeneration) and 
1990 Toureg assault kills 30 to mark period of open rebellion.

1996 Military Coup ends political stand-off that paralysed the first democratically elected government in Niger's history (8)

2004 - 2005 Famine early end to the rains and localized desert locust damage to crops and pasture lands adversely impacted Niger's pasture and cereal production, resulting in a food security crisis in the agro-pastoral and pastoral zones.

References: (1) 2001 Grolier Multimedia Encyclopedia, (2000 Grolier Interactive Inc.;

(2) http://www.discoverfrance.net/Colonies/Niger.shtml.; (3) Brough and Kimenyi 2004; (4) WRI 2008, (5) UNDRO 1985 (6)

MacDonald 1986 (7) Nicholson 1983 (8) Posthumus, B. 2000; (9) Furber, A.H. 1997 